\section{The Thermodynamic Dissociation Constants of Clotrimazole, Terbinafine HCL, Acetylsalicylic Acid, Salicylic Acid, and Galanthamine by the Nonlinear Regression of Multiwavelength Spectrophotometric pH-Titration Data}

\author{
Milan Meloun, ${ }^{1}$ Sylva Bordovská, ${ }^{1}$ and Lubomír Galla² \\ ${ }^{1}$ Department of Analytical Chemistry, University of Pardubice, 53210 Pardubice, Czech Republic \\ ${ }^{2}$ Recordati Group, Herbacos Bofarma, Ltd., Strossova 239, 53002 Pardubice, Czech Republic
}

Correspondence should be addressed to Milan Meloun, milan.meloun@upce.cz

Received 29 December 2009; Revised 12 January 2010; Accepted 26 January 2010

Copyright (C) 2010 Milan Meloun et al. This is an open access article distributed under the Creative Commons Attribution License, which permits unrestricted use, distribution, and reproduction in any medium, provided the original work is properly cited.

\begin{abstract}
The mixed dissociation constants of five drugs_clotrimazole, terbinafine $\mathrm{HCl}$, acetylsalicylic acid, salicylic acid, and galanthamineat various ionic strengths $I$ and at temperatures of $25^{\circ} \mathrm{C}$ and $37^{\circ} \mathrm{C}$ were determined with the use of multiwavelength and multivariate treatments of spectral data SPECFIT/32 nonlinear regression analysis and INDICES factor analysis. The factor analysis in the INDICES program predicts the number of components, when the data quality is high and the instrumental error is known. The thermodynamic dissociation constant $\mathrm{p} K_{\mathrm{a}}^{\mathrm{T}}$ was estimated by nonlinear regression of $\left\{\mathrm{p} K_{\mathrm{a}} I\right\}$ data at $25^{\circ} \mathrm{C}$ and $37^{\circ} \mathrm{C}$ : for clotrimazole $\mathrm{p} K_{\mathrm{a}, 1}^{\mathrm{T}}=4.38(1)$ and 4.16(3); for terbinafine $\mathrm{HCl} \mathrm{p} K_{\mathrm{a}, 1}^{\mathrm{T}}=4.19(3)$ and 4.12(5); for acetylsalicylic acid $\mathrm{p} K_{\mathrm{a}, 1}^{\mathrm{T}}=3.49(25)$ and 3.41(15); for salicylic acid $\mathrm{p} K_{\mathrm{a}, 1}^{\mathrm{T}}=3.01(1)$ and 3.00(1) and for galanthamine $\mathrm{p} K_{\mathrm{a}, 1}^{\mathrm{T}}=8.21(1)$ and $7.99(2)$ where in brackets the standard deviation is in the last significant digits. Goodness-of-fit tests for various regression diagnostics enabled the reliability of the parameter estimates found to be proven. Pharma Algorithms predicts $\mathrm{p} K_{\mathrm{a}}$ being based on the structural formulae of drug compounds.
\end{abstract}

\section{Introduction}

Acid dissociation constants ( $\mathrm{p} K_{\mathrm{a}}$ values) are key parameters to predict the extent of ionization of functional groups with respect to $\mathrm{pH}$ and also to explain chemical phenomena such as absorption, distribution, elimination of substances, biological activity, biological uptake, biological transport and environmental fate [1-3]. This information is important in drug discovery and development since the pharmacokinetic and pharmacodynamic properties of different protonation/dissociation forms of the drug molecules may vary considerably. There are several methods for the determination of dissociation constants. Traditionally, potentiometry and UV-VIS spectrometry have been the most useful techniques for the determination of equilibrium constants. Spectrophotometric methods in combination with suitable chemometric tools can be used for the determination of acid dissociation constants $\mathrm{p} K_{\mathrm{a}}$ even for barely soluble drugs provided that the compound under consideration possesses chromophore(s) in proximity to the ionization centre, but the absorptivity should also change significantly on (de)protonation, indicating that the ionization centre is a part of the chromophore. The information can be extracted if multivariate spectrophotometric data are analyzed by means of an appropriate multivariate data analysis method. Hard-modelling methods, for example SQUAD(84) [4-11], include traditional least squares curve fitting approaches, based on a previous postulation of the chemical (here protonation) model. The postulations are a set of variously protonated species defined by their stoichiometric coefficients and protonation constants, which are refined by the leastsquares minimization. However, a hard-modelling analysis cannot be applied if crucial information is missing. Softmodelling or model-free approaches, for example SPECFIT [12-16], are based on much more general prerequisites, such as positive molar absorbance, positive concentration of all species, unimodality of concentration profiles, and closure, that is, a concentration of all species is the same for all 
solutions. Naturally, if the strengths of hard-modelling and soft-modelling methodologies are combined, a much more powerful method of data analysis can be expected.

In addition, relevant software has been developed for the rapid estimation of $\mathrm{p} K_{\mathrm{a}}$ values based on the chemical structure [17]. These techniques have certain advantages, for example, calculations can be performed on large virtual compound libraries. By entering the compound topological structure descriptors graphically, $\mathrm{p} K_{\mathrm{a}}$ values of drug compounds are predicted using approximately hundreds of Hammett and Taft equations and quantum chemistry calculus. Still, erroneous data are often predicted for complex and flexible drug compounds containing several functional groups. Furthermore, these calculations are based on parameters in databases containing experimental data from the literature. Hence, sufficient data for new types of compounds, to give accurate predictions, may be missing.

An antifungal drug is a medication used to treat fungal infections such as athlete's foot, ringworm, candidiasis (thrush), serious systemic infection such as cryptococcal meningitis, and other. Such drugs are usually obtained by a doctor's prescription or purchased over-the-counter. Antifungals work by exploiting differences between mammalian and fungal cells to kill off the fungal organism without dangerous effects on the host. Unlike bacteria, both fungi and humans are eukaryotes. The basic structure of fungal cells and human cells is nearly identical. This means it is more difficult to find a target for an antifungal drug to attack that does not also exist in the infected organism. Consequently, there are often side-effects to some of these drugs. Some of these side-effects can be life-threatening if not used properly.

Clotrimazole (CLO) (chemically 1-[(2-chlorophenyl)diphenyl-methyl]imidazole, CAS no. 23593-75-1, molecular formula: $\mathrm{C}_{22} \mathrm{H}_{11} \mathrm{ClN}_{2}$, molecular weight: 344.837 , description: a colourless, odourless, tasteless and crystalline solid, solubility: it is practically insoluble in water $(<0.01 \mathrm{mg} / \mathrm{mL})$, soluble in chloroform and methanol, in ethanol and in diethyl ether, it is freely soluble in acetone and methyl alcohol, is a weak base having a $\mathrm{p} K_{\mathrm{a}}$ value of 4.7) is of the following structure:

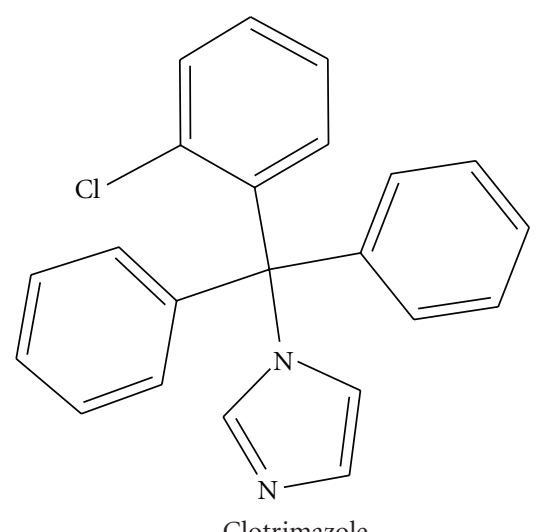

Clotrimazole, an imidazole derivative with a broad spectrum of antimycotic activity, inhibits biosynthesis of the sterol ergostol, an important component of fungal cell membranes. Its action leads to increased membrane permeability and apparent disruption of enzyme systems bound to the membrane. Betamethasone and clotrimazole are used together to treat cutaneous tinea infections. It is a well-established drug used in dermatology and gynaecology, available in the form of solution formulations, tablet and cream [18-20].

Terbinafine hydrochloride (TER-HCl) (chemically (E)-N(6,6-dimethyl-2-hepten-4-ynyl)- $N$-methyl-1-naphthalene methanamine hydrochloride, CAS no. 78628-80-5, molecular formula: $\mathrm{C}_{21} \mathrm{H}_{25} \mathrm{ClN}$, molecular weight: 327.90 , description: white to off-white finely crystalline powder, solubility: soluble in ethanol $(45 \mathrm{mg} / \mathrm{mL})$, DMSO $(30 \mathrm{mg} /$ $\mathrm{mL})$, water $(3 \mathrm{mg} / \mathrm{mL}))$ is of the following structure:

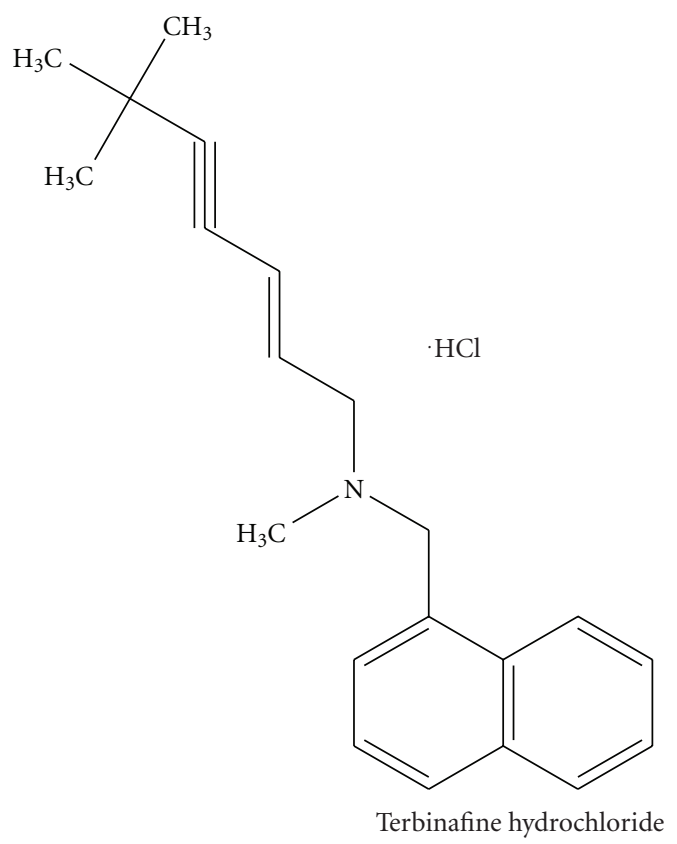

Terbinafine hydrochloride is a new potent antifungal agent of the allylamine class that selectively inhibits fungal squalene epoxidase. The drug has broad-spectrum activity against yeast, fungi, moulds, and dermatophytes and is indicated for both oral and topical treatment of mycoses [21-23].

The salicylates are a group of analgesics, or painkilling drugs, that are derivatives of salicylic acid. The best known is acetylsalicylic acid, or aspirin. Now often made synthetically, they were originally derived from salicin, the active ingredient in willow bark, used for centuries in the treatment of pain and fever. Salicylates also occur naturally in many plants used as foods (e.g., strawberries, almonds, tomatoes). Methyl salicylate is the main component of wintergreen, sweet birch, gautheria, and betula oils; the compound is used in rubbing liniments to soothe muscular aches and as a flavouring. Sodium salicylate, traditionally used in the treatment of arthritis, is also used in dyes and as a nonedible preservative. In general, salicylates, especially aspirin, are used medically to reduce fever and inflammation and to relieve headache, menstrual pain, and pain in nerves, muscles, and joints. Because of the effects of salicylates on blood platelets and clotting, aspirin is often prescribed prophylactically for those at risk of stroke or heart attack. Salicylates are useful, relatively safe drugs, but normal doses 
can cause gastrointestinal disturbances in sensitive patients and large doses can be toxic or fatal, especially to children.

Acetylsalicylic Acid (ASA) (chemically 2-Acetoxybenzoic acid, CAS no. 50-78-2, description: colourless or a white crystalline powder, molecular formula: $\mathrm{C}_{9} \mathrm{H}_{8} \mathrm{O}_{4}$, molecular weight: 180.16 , melting point: $138-140^{\circ} \mathrm{C}$, solubility: 1 in 300 of water, 1 in 5-7 in alcohol, 1 in 17 of chloroform and 1 in 20 of ether; soluble in solutions of acetates and citrates and, with decomposition, in solutions of alkali hydroxides and carbonates, $\mathrm{p} K_{\mathrm{a}}$ is 3.49 at $25^{\circ} \mathrm{C}$ [24]) of the structure<smiles>CC(=O)Oc1ccccc1C(=O)O</smiles>

Acetylsalicylic acid

is arguably the world's oldest and best known pharmaceutical product with accepted anti-inflammatory, anti-thrombotic, anti-pyretic, anti-oxidant and analgesic properties [25-27]. It has been suggested that daily use of aspirin can reduce the risk of some types of cancer [28], and even provide a means of extending human life [29]. Aspirin was the first-discovered member of the class of drugs known as nonsteroidal anti-inflammatory drugs (NSAIDs), not all of which are salicylates, although they all have similar effects and a similar mechanism of action.

Salicylic Acid (SA) (chemically 2-Hydroxybenzoic acid, CAS no. 69-72-7, description: colourless or white crystalline powder, molecular formula: $\mathrm{C}_{7} \mathrm{H}_{6} \mathrm{O}_{3}$, molecular weight: 138.12 , melting point: $160^{\circ} \mathrm{C}$, solubility: soluble 1 in 460 to 550 of water, 1 in 15 of boiling water, 1 in 3 to 4 in alcohol, 1 in 3 in ether, and 1 in 45 in chloroform, $\mathrm{p} K_{\mathrm{a}}$ is 3.00 at $25^{\circ} \mathrm{C}$ ) of the structure

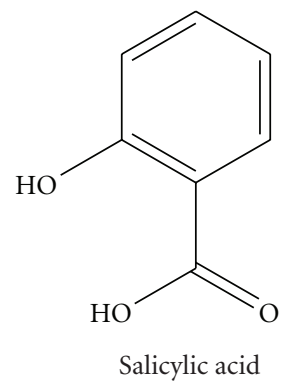

is a beta hydroxy acid (BHA). This colourless crystalline organic acid is widely used in organic synthesis and functions as a plant hormone. It is derived from the metabolism of salicin. It is probably best known as a compound that is chemically similar but not identical to the active component of aspirin. It is widely used as kerotalic, antimicrobial and antifungal agent and as an external therapeutical agent (keratolytic) in many pharmaceutical preparations [30, 31].

Galanthamine (GAL) belongs to a class of acetylcholinesterase inhibitors approved for symptomatic treatment of
Alzheimer's disease. Galanthamine (chemically (4aS,6R, 8aS)-4a,5,9,10,11,12-Hexahydro-3-methoxy-11-methyl-6Hbenzofuro[3a,3,2-ef] [2] benzazepin-6-ol, CAS no. 357-70-0, description: a white crystalline powder, molecular formula: $\mathrm{C}_{17} \mathrm{H}_{21} \mathrm{NO}_{3}$, molecular weight: 287.358, melting point: $127-128^{\circ} \mathrm{C}$, solubility: poorly soluble in water, $\mathrm{p} K_{\mathrm{a}}$ is 8.2 at $25^{\circ} \mathrm{C}$ ) of structure

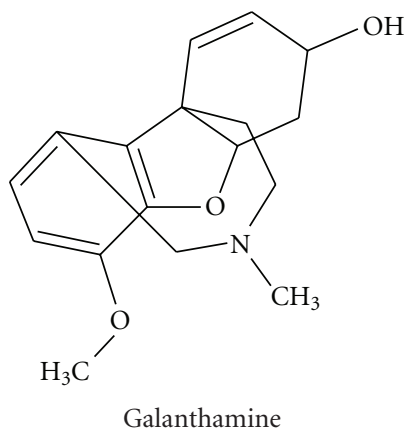

is a parasympathomimetic, specifically, a reversible cholinesterase inhibitor. It is indicated for the treatment of mild to moderate dementia of the Alzheimer's type. Galanthamine is postulated to exert its therapeutic effect by enhancing cholinergic function. This is accomplished by increasing the concentration of acetylcholine through reversible inhibition of its hydrolysis by acetylcholinesterase. If this proposed mechanism of action is correct, galanthamine's effect may lessen as the disease process advances and fewer cholinergic neurons remain functionally intact. There is no evidence that galanthamine alters the course of the underlying dementing process [32-36].

The procedure for the determination of the mixed protonation/dissociation constants has been described previously [37-40]. The details of the computer data treatment are collected in the Supporting Information. The nonlinear estimation of the thermodynamic dissociation constant $K_{\mathrm{a}}^{\mathrm{T}}=a_{H^{+}} a_{L^{-}} / a_{H L}$, is simply a problem of optimization in the parameter space in which $\mathrm{p} K_{\mathrm{a}}$ and $I$ are known and given values, while the parameters $\mathrm{p} K_{\mathrm{a}}^{\mathrm{T}}, a$, and $C$ are unknown variables to be estimated $[41,42]$. The adequacy of a proposed regression model with experimental data and the reliability of parameter estimates $\mathrm{p} K_{\mathrm{a}, \mathrm{i}}$ found, being denoted for the sake of simplicity as $b_{j}$, and $\varepsilon_{i j}, j=1, \ldots, m$, may be examined by a goodness-of-fit test, cf. a previous tutorial [37-40]. Repeatability and reproducibility (R\&R) are critical factors closely related to precision and accuracy. It helps to think of repeatability in terms of how capable the gage is of providing the same reading to a single user when measuring a specific sample. Repeatability is the variability of the measurements obtained by one person while measuring the same item repeatedly. This is also known as the inherent precision of the measurement equipment. Reproducibility is the variability of the measurement system caused by differences in operator behaviour. Mathematically, it is the variability of the average values obtained by several operators while measuring the same item.

The aim of the study was to determine the $\mathrm{p} K_{\mathrm{a}}^{\mathrm{T}}$ values of clotrimazole, terbinafine $\mathrm{HCl}$, acetylsalicylic acid, salicylic acid, and galanthamine using $\mathrm{pH}$-spectrophotometric 
TABle 1: Dependence of the mixed dissociation constants $\mathrm{p} K_{a}$ of clotrimazole on ionic strength using regression analysis of $\mathrm{pH}$ spectrophotometric data with SPECFIT at $25^{\circ} \mathrm{C}$ and $37^{\circ} \mathrm{C}$. The standard deviations of the parameter $\mathrm{p} K_{a}$ in the last valid digits are in brackets.

\begin{tabular}{|c|c|c|c|c|c|c|c|c|}
\hline \multicolumn{9}{|c|}{ Estimated $\mathrm{p} K_{\mathrm{a}}$ at $25^{\circ} \mathrm{C}$} \\
\hline \multirow{3}{*}{ SPECFIT } & Ionic strength & 0.002 & 0.025 & 0.040 & 0.048 & 0.055 & 0.086 & 0.116 \\
\hline & $\mathrm{p} K_{\mathrm{a}}$ & $4.360(32)$ & $4.325(24)$ & $4.337(24)$ & $4.318(13)$ & $4.338(23)$ & $4.333(24)$ & $4.337(17)$ \\
\hline & $s(\mathrm{~A})[\mathrm{mAU}]$ & 0.85 & 0.80 & 0.51 & 0.65 & 0.77 & 0.95 & 0.94 \\
\hline \multicolumn{9}{|c|}{ Estimated $\mathrm{p} K_{\mathrm{a}}$ at $37^{\circ} \mathrm{C}$} \\
\hline \multirow{3}{*}{ SPECFIT } & Ionic strength & 0.017 & 0.025 & 0.033 & 0.040 & 0.063 & 0.071 & 0.116 \\
\hline & $\mathrm{p} K_{\mathrm{a}}$ & $4.152(27)$ & $4.072(26)$ & $4.037(18)$ & $4.073(11)$ & $4.030(18)$ & $4.066(21)$ & $4.037(17)$ \\
\hline & $s(\mathrm{~A})[\mathrm{mAU}]$ & 0.74 & 0.59 & 0.80 & 0.57 & 0.97 & 0.85 & 0.84 \\
\hline
\end{tabular}

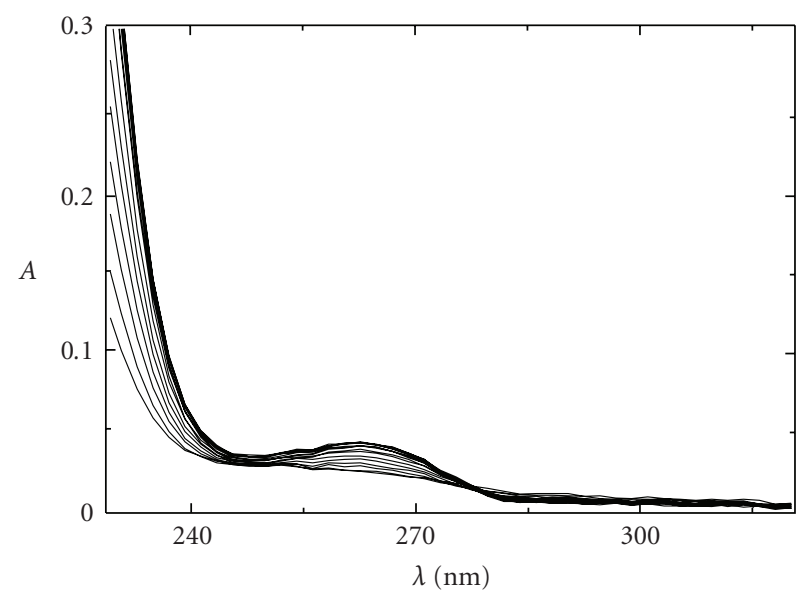

(a)

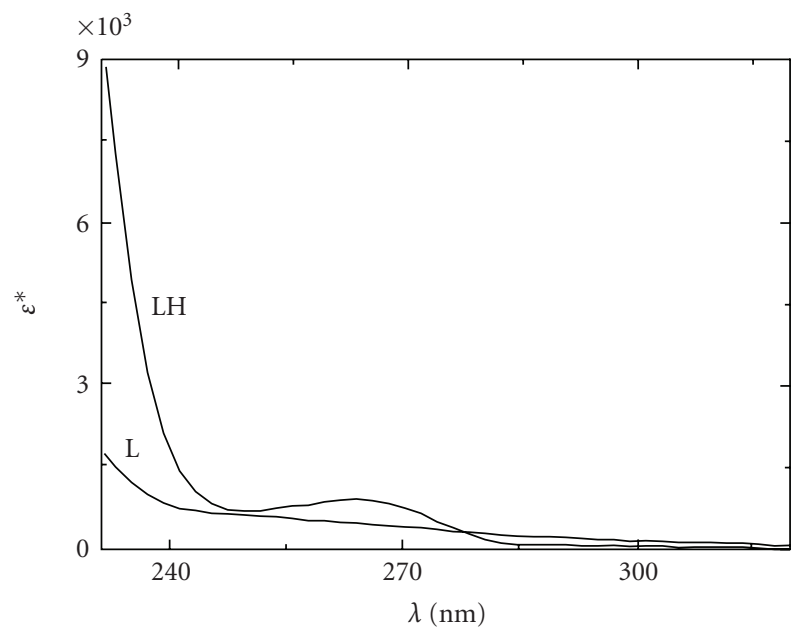

(c)

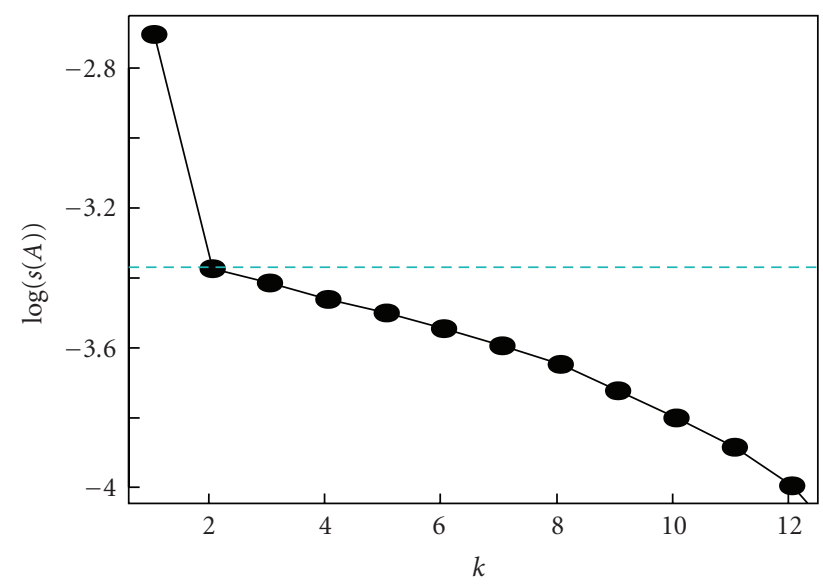

(b)

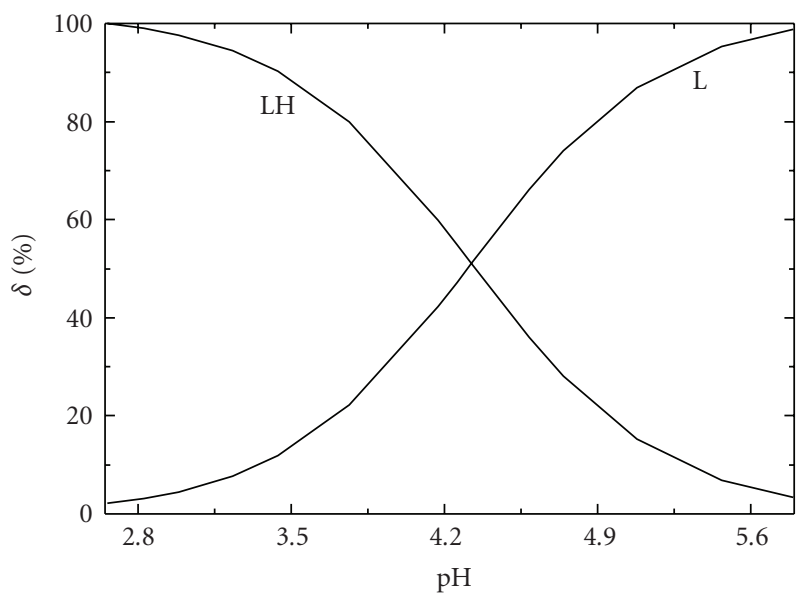

(d)

FIGURE 1: The nonlinear regression analysis of the protonation equilibria model and factor analysis of clotrimazole: (a) Absorption spectra in dependence on $\mathrm{pH}$ at $25^{\circ} \mathrm{C}$, (b) Cattel's scree plot of the Wernimont-Kankare procedure for determination of the number of light-absorbing species in the mixture $k^{*}=2$ leads to the actual instrumental error of the spectrophotometer used $s_{\text {inst }}(A)=0.43$ mAU (INDICES in S-Plus), (c) Pure spectra profiles of molar absorptivities versus wavelengths for species L and LH, (d) Distribution diagram of the relative concentrations of species $\mathrm{L}$ and $\mathrm{LH}$ of clotrimazole in dependence on $\mathrm{pH}$ at $25^{\circ} \mathrm{C}$. The charges of species are omitted for the sake of simplicity. (SPECFIT, ORIGIN). 
TABle 2: Dependence of the mixed dissociation constants $\mathrm{p} K_{\mathrm{a}}$ of terbinafine hydrochloride on ionic strength using regression analysis of $\mathrm{pH}$-spectrophotometric data with SPECFIT at $25^{\circ} \mathrm{C}$ and $37^{\circ} \mathrm{C}$. The standard deviations of the parameter pK in the last valid digits are in brackets.

\begin{tabular}{|c|c|c|c|c|c|c|c|c|}
\hline & \multicolumn{8}{|c|}{ Estimated $\mathrm{p} K_{\mathrm{a}}$ at $25^{\circ} \mathrm{C}$} \\
\hline \multirow{4}{*}{ SPECFIT } & Ionic strength & 0.002 & 0.017 & 0.032 & 0.040 & 0.048 & 0.055 & 0.070 \\
\hline & $\mathrm{p} K_{\mathrm{a}}$ & $4.212(2)$ & $4.347(4)$ & $4.527(1)$ & $4.617(2)$ & $4.599(1)$ & $4.768(2)$ & $4.900(3)$ \\
\hline & $s(\mathrm{~A})[\mathrm{mAU}]$ & 0.93 & 1.05 & 1.00 & 0.81 & 1.04 & 0.55 & 1.40 \\
\hline & \multicolumn{8}{|c|}{ Estimated $\mathrm{p} K_{\mathrm{a}}$ at $37^{\circ} \mathrm{C}$} \\
\hline \multirow{3}{*}{ SPECFIT } & Ionic strength & \multicolumn{2}{|c|}{0.002} & \multicolumn{2}{|c|}{0.032} & 0.048 & 0.063 & 0.078 \\
\hline & $\mathrm{p} K_{\mathrm{a}}$ & \multicolumn{2}{|c|}{$4.136(2)$} & \multicolumn{2}{|c|}{$4.276(1)$} & $4.282(2)$ & $4.470(1)$ & $4.474(2)$ \\
\hline & $s(\mathrm{~A})[\mathrm{mAU}]$ & \multicolumn{2}{|c|}{0.82} & \multicolumn{2}{|c|}{0.65} & 1.00 & 0.50 & 0.98 \\
\hline
\end{tabular}

TABle 3: Repeatability of measurements. The standard deviations of the parameter $\mathrm{p} K_{\mathrm{a}}$ in the last valid digits are in brackets.

\begin{tabular}{lccccc}
\hline No. & $\begin{array}{c}\text { Estimated } \\
\mathrm{p} K_{\mathrm{a}} \text { at } 25^{\circ} \mathrm{C}\end{array}$ & $\begin{array}{c}s(\mathrm{~A}) \\
{[\mathrm{mAU}]}\end{array}$ & No. & $\begin{array}{c}\text { Estimated } \\
\mathrm{p} K_{\mathrm{a}} \text { at } 37^{\circ} \mathrm{C}\end{array}$ & $\begin{array}{c}s(\mathrm{~A}) \\
{[\mathrm{mAU}]}\end{array}$ \\
\hline 1 & $3.514(7)$ & 0.83 & 1 & $3.440(15)$ & 0.83 \\
2 & $3.481(10)$ & 0.95 & 2 & $3.413(11)$ & 0.75 \\
3 & $3.447(11)$ & 0.96 & 3 & $3.400(13)$ & 1.19 \\
4 & $3.510(6)$ & 1.00 & 4 & $3.422(14)$ & 0.96 \\
5 & $3.505(13)$ & 0.98 & 5 & $3.403(7)$ & 0.83 \\
6 & $3.498(11)$ & 0.88 & 6 & $3.405(11)$ & 0.95 \\
\hline Sample & \multirow{2}{*}{$3.493(25)$} & & & $3.414(15)$ & \\
mean & & & & &
\end{tabular}

titrations. The $\mathrm{p} K_{\mathrm{a}}$ values were also calculated theoretically using computer program (Pharma Algorithms) making predictions based on the structural formula of drug compounds.

\section{Experimental}

2.1. Materials. Clotrimazole was purchased from AMOLI ORGANICS Ltd., with a purity of $100 \%$. Terbinafine $\mathrm{HCl}$ was purchased from CHEMAGIS, with a purity of $100 \%$. Acetylsalicylic Acid was purchased from Sigma-Aldrich Co., with a purity of $\geq 99 \%$. Salicylic Acid was purchased from Sigma-Aldrich Co., with a purity of $\geq 99 \%$. Galanthamine was purchased from Ivax-Pharmaceuticals s.r.o., with a purity of $\geq 99 \%$. Perchloric acid, $1 \mathrm{M}$, was prepared from conc. $\mathrm{HClO}_{4}$ (p.a., Lachema Brno) using redistilled water and standardized against $\mathrm{HgO}$ and $\mathrm{NaI}$ with reproducibility of less than $0.20 \%$. Sodium hydroxide, $1 \mathrm{M}$, was prepared from pellets (p.a., Aldrich Chemical Company) with carbondioxidefree redistilled water and standardized against a solution of potassium hydrogen-phthalate using the Gran Method with a reproducibility of $0.1 \%$. Mercuric oxide, sodium iodide, and sodium perchlorate (p.a. Lachema Brno) were not further purified. The preparation of other solutions from analytical reagent-grade chemicals has been described previously [37-40].

2.2. Apparatus and Procedure. The apparatus used and the $\mathrm{pH}$-spectrophotometric titration procedure described in $[37-40]$ were applied. The microscale $\mathrm{pH}$-titrimetric method generally decreases the amount of drug sample required but the duration of experiment is as long as that of a conventional titration. This method uses $\mathrm{pH}$ electrodes which requires the calibration of the $\mathrm{pH}$ electrodes cell every day. Calibration procedures normally take 20 minutes and the $E^{0}$ and slope of the electrode remain valid for less than 1 day. The free hydrogen-ion concentration $h=\left[\mathrm{H}^{+}\right]$was measured via emf on an OP208/1 digital voltmeter (Radelkis, Budapest) with a precision of $\pm 0.1 \mathrm{mV}$ using a G202B glass electrode (Radiometer, Copenhagen) and an OP-8303P commercial SCE reference electrode (Radelkis, Budapest). Although spectrophotometric multiple-wavelength $\mathrm{pH}$-titration has gained popularity in recent years, the method also requires precise $\mathrm{pH}$ measurement: an aqueous solution $20.00 \mathrm{~cm}^{3}$ containing $10^{-5} \mathrm{~mol} . \mathrm{dm}^{-3}$ drug, $0.100 \mathrm{~mol} \cdot \mathrm{dm}^{-3}$ hydrochloric acid and $10 \mathrm{~cm}^{3}$ indifferent solution $\mathrm{KCl}$ for adjustment of ionic strength was titrated with standard $1.0 \mathrm{~mol} \cdot \mathrm{dm}^{-3}$ $\mathrm{KOH}$ at $298 \mathrm{~K}$ and from 20 to 50 absorption spectra were recorded. Titrations were performed in a thermostatic waterjacketed double-walled glass vessel of $100 \mathrm{~mL}$, closed with a Teflon bung containing the electrodes, an argon inlet, a thermometer, a propeller stirrer and a capillary tip from a micro-burette. All $\mathrm{pH}$ measurements were carried out at $25.0^{\circ} \mathrm{C} \pm 0.1^{\circ}$ and $37.0^{\circ} \mathrm{C} \pm 0.1^{\circ}$. As all methods involving the use of $\mathrm{pH}$ electrodes have the same limitation, namely, relatively extensive experimental time. During titration, the average $\mathrm{pH}$ meter responses time can be as long as 0.5 minute for each recorded point even with the best $\mathrm{pH}$ electrodes. Therefore, a typical titration process takes approximately $30 \mathrm{~min}$ to cover the whole $\mathrm{pH}$ range with $0.1 \mathrm{pH}$ unit intervals necessary to provide the high quality data suitable for analysis. As the uniformity of the solution can be achieved quickly by vigorous stirring, and typical proton dissociation processes are less than $10^{-8} \mathrm{~s}$, much time during $\mathrm{pH}$ titration experiments is wasted, waiting for the electrode to provide a stable response.

When the drug was titrated, a stream of argon gas was bubbled through the solution both to stir and to maintain an inert atmosphere. The argon was passed through an aqueous ionic medium by prior passage through one or two vessels also containing the titrand medium before entering the corresponding titrand solution. The burettes used were syringe micro-burettes of $1250 \mu \mathrm{L}$ capacity (META, Brno) with a $2.50 \mathrm{~cm}$ micrometer screw, [43]. The polyethylene 


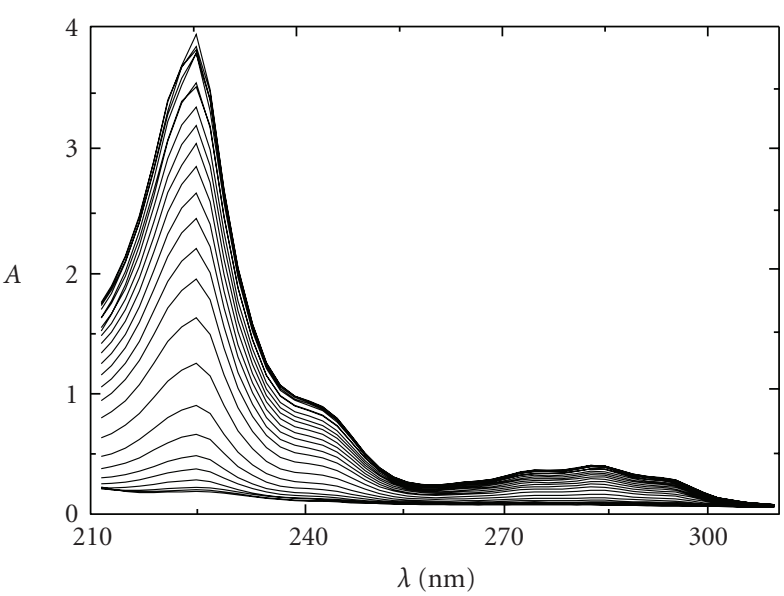

(a)

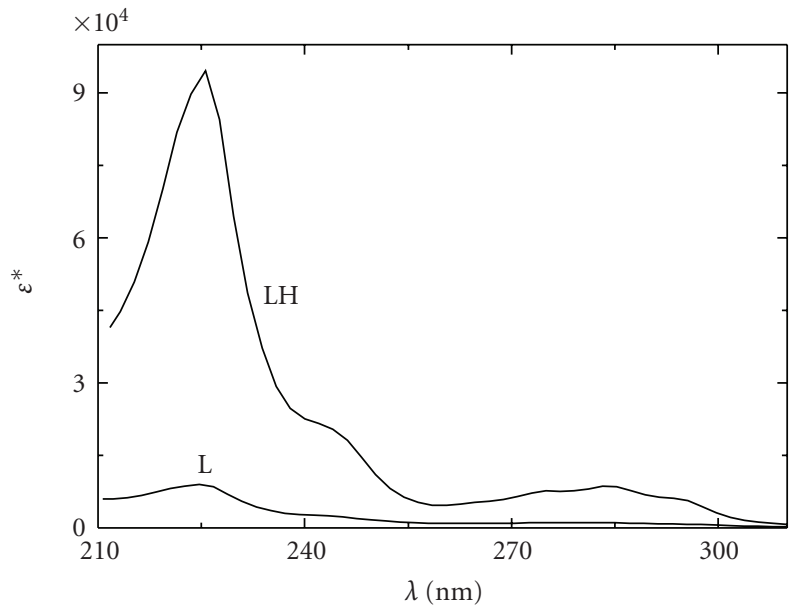

(c)

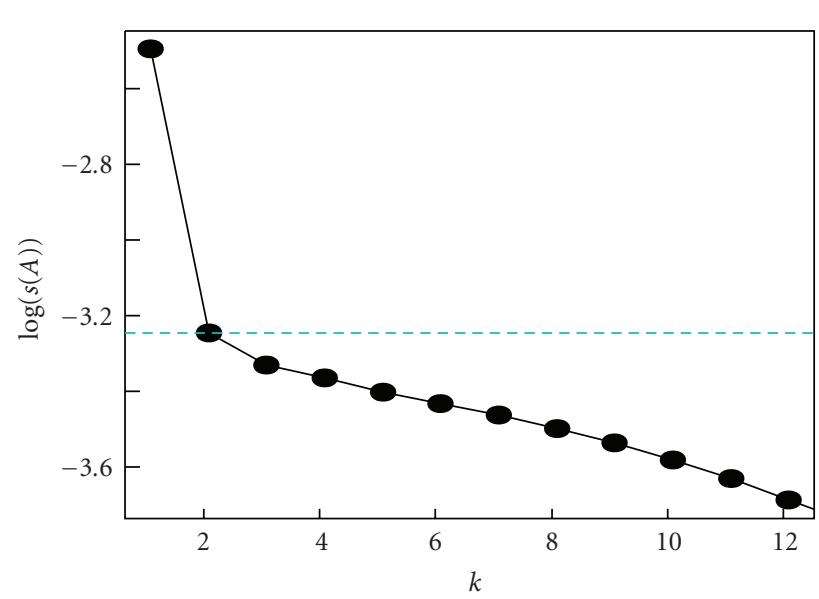

(b)

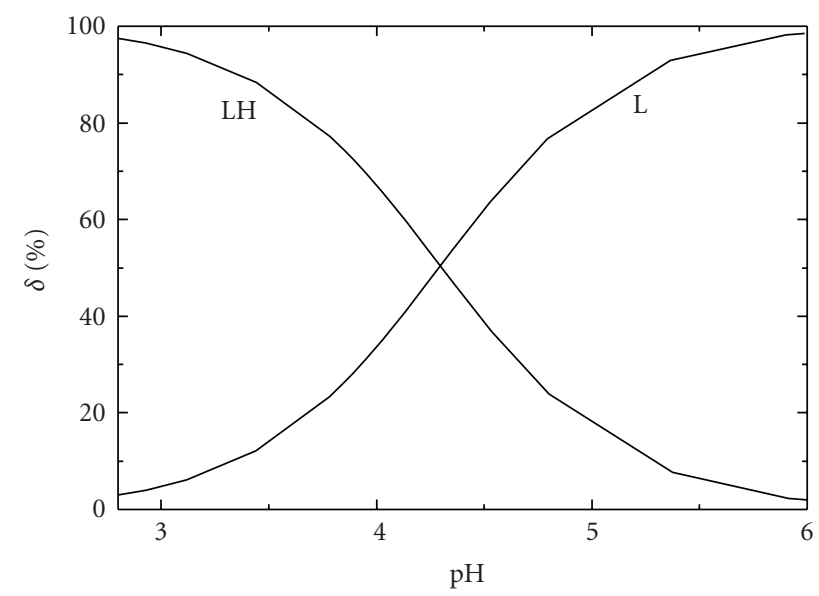

(d)

FIGURE 2: The nonlinear regression analysis of the protonation equilibria model and factor analysis of terbinafine hydrochloride: (a) Absorption spectra in dependence on $\mathrm{pH}$ at $25^{\circ} \mathrm{C}$, (b) Cattel's scree plot of the Wernimont-Kankare procedure for determination of the number of light-absorbing species in the mixture $k^{*}=2$ leads to the actual instrumental error of the spectrophotometer used $s_{\text {inst }}(A)=0.56 \mathrm{mAU}$ (INDICES in S-Plus), (c) Pure spectra profiles of molar absorptivities versus wavelengths for species L and LH, (d) Distribution diagram of the relative concentrations of species $\mathrm{L}$ and $\mathrm{LH}$ of terbinafine hydrochloride in dependence on $\mathrm{pH}$ at $25^{\circ} \mathrm{C}$. The charges of species are omitted for the sake of simplicity. (SPECFIT, ORIGIN).

capillary tip of the micro-burette was immersed into the solution when adding reagent, but withdrawn after each addition in order to avoid leakage of the reagent during the $\mathrm{pH}$ read out. The micro-burette was calibrated by ten replicate determinations of the total volume of delivered water by weighing on a Sartorius 1712 MP8 balance with results evaluated statistically, leading to a precision of $\pm 0.015 \%$ in added volume over the whole volume range. The solution was pumped into the cuvette and spectrophotometric measurement was performed with the use of a Cintra 40 spectrophotometer (GBC, Australia).

The computation scheme for the determination of the protonation constants of the multicomponent system is taken from Meloun et al., cf. [1, page 226] and the five steps are described elsewhere [37-40, 44-48]: (1) instrumental error of absorbance measurements, $s_{\text {inst }}(A),(2)$ experimental design, (3) number of light-absorbing species with a factor analysis, (4) choice of computational strategy of the nonlinear regression, (5) diagnostics indicating a correct chemical (protonation) model: when a minimization process terminates, some curve-fitting diagnostics are examined to determine whether the results should be accepted: the physical meaning of parametric estimates, the physical meaning of the species concentrations, the goodness-offit test of spectra calculated, and the deconvolution of the experimental spectra set.

2.3. Computations. Computations relating to the determination of dissociation constants were performed by regression analysis of the UV/VIS spectra using the SPECFIT/32 [1216] programmes. Most of graphs were plotted using ORIGIN 7.5 [49] and S-Plus [50]. The thermodynamic dissociation constant $\mathrm{p} K_{\mathrm{a}}^{\mathrm{T}}$ was estimated with the MINOPT nonlinear regression programme in the ADSTAT statistical system [51]. 


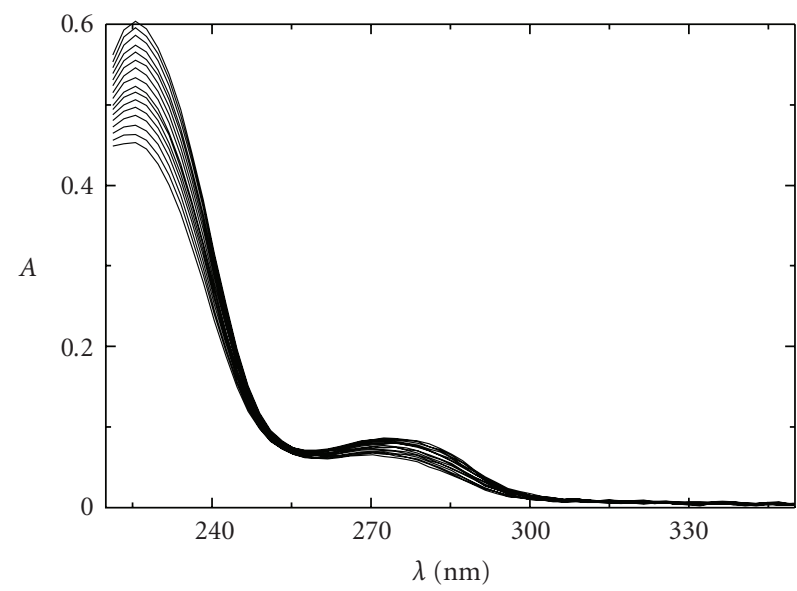

(a)

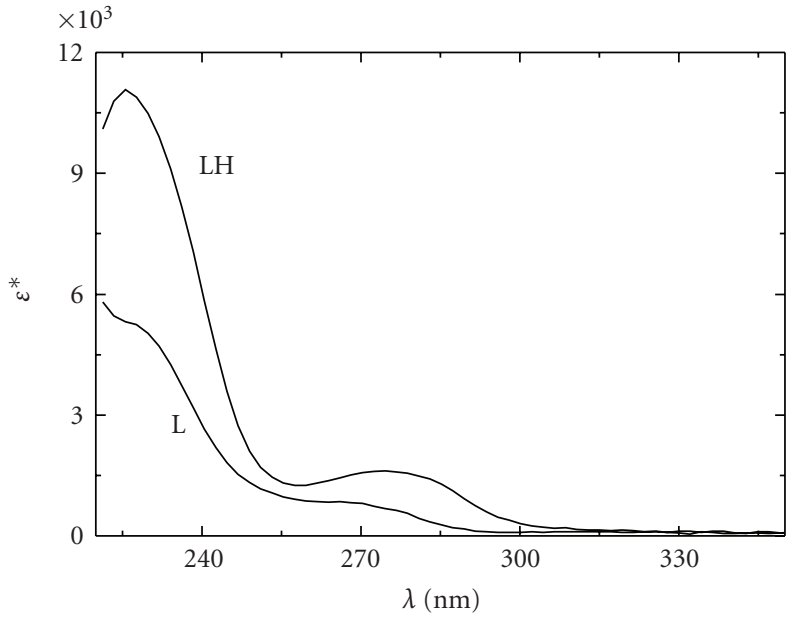

(c)

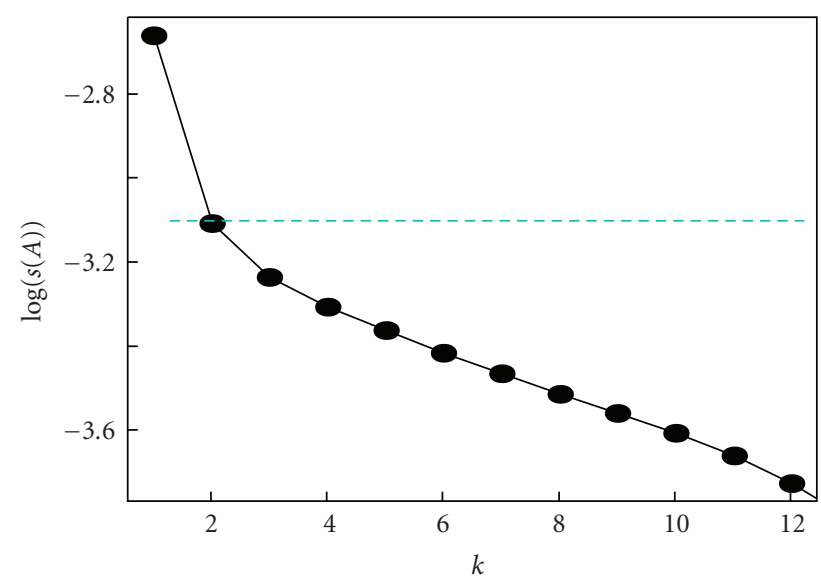

(b)

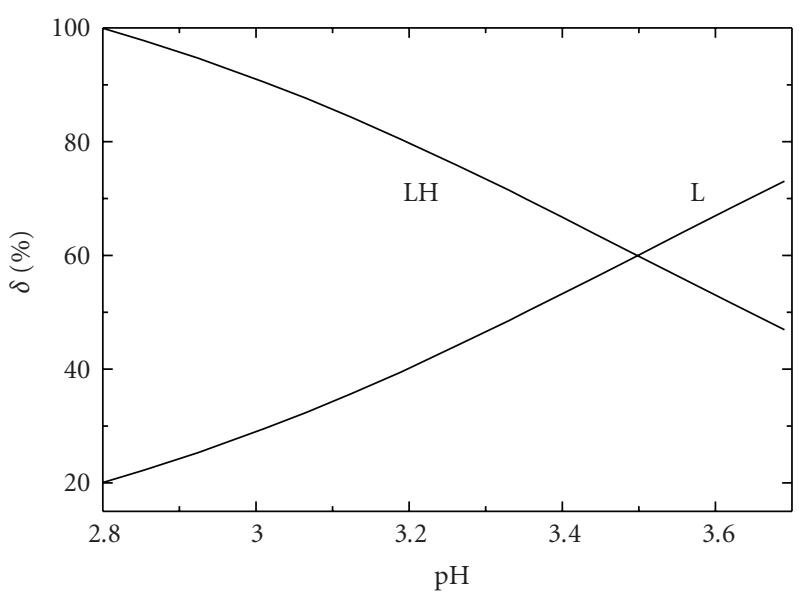

(d)

FIgURE 3: The nonlinear regression analysis of the protonation equilibria model and factor analysis of acetylsalicylic acid: (a) Absorption spectra in dependence on $\mathrm{pH}$ at $25^{\circ} \mathrm{C}$, (b) Cattel's scree plot of the Wernimont-Kankare procedure for determination of the number of light-absorbing species in the mixture $k^{*}=2$ leads to the actual instrumental error of the spectrophotometer used $s_{\text {inst }}(A)=0.79 \mathrm{mAU}$ (INDICES in S-Plus), (c) Pure spectra profiles of molar absorptivities versus wavelengths for species L and LH, (d) Distribution diagram of the relative concentrations of species $\mathrm{L}$ and $\mathrm{LH}$ of acetylsalicylic acid in dependence on $\mathrm{pH}$ at $25^{\circ} \mathrm{C}$. The charges of species are omitted for the sake of simplicity. (SPECFIT, ORIGIN).

A qualitative interpretation of the spectra with the use of the INDICES programme [52] aims to evaluate the quality of the dataset and remove spurious data, and to estimate the minimum number of factors, that is, contributing aqueous species, which are necessary to describe the experimental data and determine the number of dominant species present in the equilibrium mixture. Pharma Algorithms [17] is a programme for making predictions based on the structural formulae of drug compounds. Entering the compound topological structure descriptors graphically, $\mathrm{p} K_{\mathrm{a}}$ values of organic compound are predicted using approximately hundreds of Hammett and Taft equations and quantum chemistry calculus.

2.4. Supporting Information Available. Complete experimental and computational procedures [37-40,44-48], input data specimens, and corresponding output in numerical and graphical form for the programmes, INDICES, SQUAD(84), and SPECFIT/32 are available free of charge on line at http://meloun.upce.cz and in the block DOWNLOAD and block DATA.

\section{Results and Discussion}

\subsection{Estimation of Dissociation Constants}

3.1.1. Clotrimazole. A suggested strategy for effective experimentation in dissociation constants determination ensued from spectral data treatment is presented on the protonation equilibria of clotrimazole. The experimental spectra are acquired for the titration of an acid $4.29 \times 10^{-5} \mathrm{M}$ clotrimazole solution by a standard solution of $1 \mathrm{M} \mathrm{NaOH}$ to adjust $\mathrm{pH}$ value. As all variously protonated anions exhibit quite 
TABle 4: Dependence of the mixed dissociation constants $\mathrm{p} K_{\mathrm{a}}$ of salicylic acid on ionic strength using regression analysis of $\mathrm{pH}-$ spectrophotometric data with SPECFIT at $25^{\circ} \mathrm{C}$ and $37^{\circ} \mathrm{C}$. The standard deviations of the parameter $\mathrm{p} K_{\mathrm{a}}$ in the last valid digits are in brackets.

\begin{tabular}{|c|c|c|c|c|c|c|c|c|c|}
\hline & \multicolumn{9}{|c|}{ Estimated $\mathrm{p} K_{\mathrm{a}}$ at $25^{\circ} \mathrm{C}$} \\
\hline \multirow{4}{*}{ SPECFIT } & Ionic strength & 0.001 & 0.017 & 0.047 & & & 0.062 & 0.069 & 0.077 \\
\hline & $\mathrm{p} K_{\mathrm{a}}$ & $2.997(20)$ & $2.977(12)$ & $2.976(15)$ & 2.97 & 17) & $2.971(12)$ & $2.971(16)$ & $2.970(16)$ \\
\hline & $s(\mathrm{~A})[\mathrm{mAU}]$ & 1.02 & 0.92 & 0.80 & & & 0.72 & 0.83 & 0.79 \\
\hline & \multicolumn{9}{|c|}{ Estimated $\mathrm{p} K_{\mathrm{a}}$ at $37^{\circ} \mathrm{C}$} \\
\hline \multirow{3}{*}{ SPECFIT } & Ionic strength & 0.001 & 0.009 & 0.017 & 0.032 & 0.039 & 0.054 & 0.062 & 0.077 \\
\hline & $\mathrm{p} K_{\mathrm{a}}$ & $2.995(13)$ & $2.939(15)$ & $2.964(11)$ & $2.917(15)$ & $2.935(14)$ & $2.929(15)$ & $2.930(17)$ & $2.917(13)$ \\
\hline & $s(\mathrm{~A})[\mathrm{mAU}]$ & 0.80 & 0.62 & 0.91 & 1.00 & 0.77 & 0.95 & 0.98 & 0.98 \\
\hline
\end{tabular}

TABle 5: Repeatability of measurements. The standard deviations of the parameter $\mathrm{p} K_{\mathrm{a}}$ in the last valid digits are in brackets.

\begin{tabular}{llc}
\hline No. & $\begin{array}{l}\text { Estimated dissociation } \\
\text { constants } \mathrm{p} K_{\mathrm{a}} \text { at } 25^{\circ} \mathrm{C}\end{array}$ & $s(\mathrm{~A})[\mathrm{mAU}]$ \\
\hline 1 & $2.914(13)$ & 0.84 \\
2 & $2.959(14)$ & 0.91 \\
3 & $2.965(15)$ & 1.00 \\
4 & $2.940(15)$ & 0.89 \\
5 & $2.935(18)$ & 0.87 \\
6 & $2.970(16)$ & 0.79 \\
7 & $2.925(21)$ & 0.87 \\
8 & $2.935(12)$ & 0.87 \\
\hline Mean from the & \\
propagation-of- & $2.943(6)$ & \\
errors & & \\
\hline Sample means & $2.943(20)$ & \\
\hline
\end{tabular}

similar absorption bands, a part of the spectrum from 240$320 \mathrm{~nm}$ was selected as the most appropriate for an estimation of protonation constants. $\mathrm{pH}$-spectrophotometric titration allows absorbance-response-surface data (Figure 1(a)) to be acquired for analysis with non-linear regression and the reliability of parameter estimates $\left(\mathrm{p} K_{\mathrm{s}}^{\prime}\right.$ and $\left.\varepsilon_{\mathrm{s}}^{\prime}\right)$ can be assessed on the basis of the goodness-of-fit test of residuals. In the first step of the spectra analysis, the number of light-absorbing species was estimated using the INDICES algorithm (Figure 1(b)). The position of the break point on the $s_{k}(A)=f(k)$ curve in the factor analysis scree plot is calculated and gives $k^{*}=2$ with the corresponding coordinate $\log \left(s_{k}^{*}(A)\right)=-3.37$ which gives the value $s_{k}^{*}(A)=$ $0.43 \mathrm{mAU}$ and which also represents the actual instrumental error $s_{\text {inst }}(A)$ of the spectrophotometer used. Very low values of $s_{\text {inst }}(A)$ prove that quite reliable spectrophotometer and experimental techniques were used. In the first run, the dissociation constant and two molar absorptivities of clotrimazole by SPECFIT/32 are estimated. The reliability of the regression parameter estimates may be tested using the following diagnostic which have been described previously [37-40]. The goodness-of-fit establishes sufficiently reliable estimates of the dissociation constant and molar absorption coefficient. Figure 1(c) shows the curves of molar absorption coefficients of $\mathrm{L}^{-}$and $\mathrm{LH}$ species in dependence on wavelength and Figure 1(d) shows the distribution diagram of $\mathrm{L}^{-}$and $\mathrm{LH}$ species in dependence on $\mathrm{pH}$. The estimated dissociation constant $\mathrm{p} K_{\mathrm{a}}$ at two temperatures $25^{\circ} \mathrm{C}$ and $37^{\circ} \mathrm{C}$ in dependence on an ionic strength $I$ is in Table 1 and Figure 6.

3.1.2. Terbinafine $\mathrm{HCl}$. The experimental spectra are acquired for the titration of an acid $4.10 \times 10^{-5} \mathrm{M}$ terbinafine $\mathrm{HCl}$ solution by a standard solution of $1 \mathrm{M}$ $\mathrm{NaOH}$ to adjust $\mathrm{pH}$ value. $\mathrm{pH}$ spectrophotometric titration allows absorbance-response data (Figure 2(a)) to be acquired for analysis by nonlinear regression, and the reliability of parameter estimates $\left(\mathrm{p} K_{s}^{\prime}\right.$ and $\left.\varepsilon_{s}^{\prime}\right)$ can be assessed on the basis of the goodness-of-fit test of residuals. As the changes in absorbance spectra are significant within deprotonation, both of the variously protonated species $\mathrm{L}^{-}$and $\mathrm{LH}$ exhibit sufficiently different absorption bands. The best region of the spectrum seems to be $240-310 \mathrm{~nm}$ and $\mathrm{p} K_{\mathrm{a}}=4.19$ $(s=0.03)$.

In the first step of the regression spectra analysis, the number of light-absorbing species is estimated by the INDICES algorithm (Figure 2(b)). The position of the break point on the $s_{k}(A)=f(k)$ curve in the factor analysis scree plot is calculated and gives $k^{*}=2$ with corresponding coordinate $\log \left(s_{k}^{*}(A)\right)=-3.25$ which gives the value $s_{k}^{*}(A)=0.56 \mathrm{mAU}$. The goodness-of-fit establishes sufficiently reliable estimates of the dissociation constant and molar absorption coefficient. Figure 2(c) shows the curves of molar absorption coefficients of $\mathrm{L}^{-}$and $\mathrm{LH}$ species in dependence on wavelength and Figure 2(d) the distribution diagram of $\mathrm{L}^{-}$and $\mathrm{LH}$ species in dependence on $\mathrm{pH}$. The estimated dissociation constant $\mathrm{p} K_{\mathrm{a}}$ at two temperatures $25^{\circ} \mathrm{C}$ and $37^{\circ} \mathrm{C}$ in dependence on an ionic strength $I$ is in Table 2 and Figure 6.

3.1.3. Acetylsalicylic Acid. The estimation of thermodynamic dissociation constant $\mathrm{p} K_{\mathrm{a}}^{\mathrm{T}}$ of acetylsalicylic acid (ASA) is quite a major problem since during preparation it may contain its main degradation product salicylic acid (SA). So during the determination of ASA, the presence of SA must be considered. The experimental spectra are acquired for the fast titration of an alkaline $5.96 \times 10^{-5} \mathrm{M}$ acetylsalicylic acid solution by a standard solution of $1 \mathrm{M} \mathrm{HCl}$ (or $\mathrm{HClO}_{4}$ ) to adjust $\mathrm{pH}$ value. $\mathrm{pH}$ spectrophotometric titration 


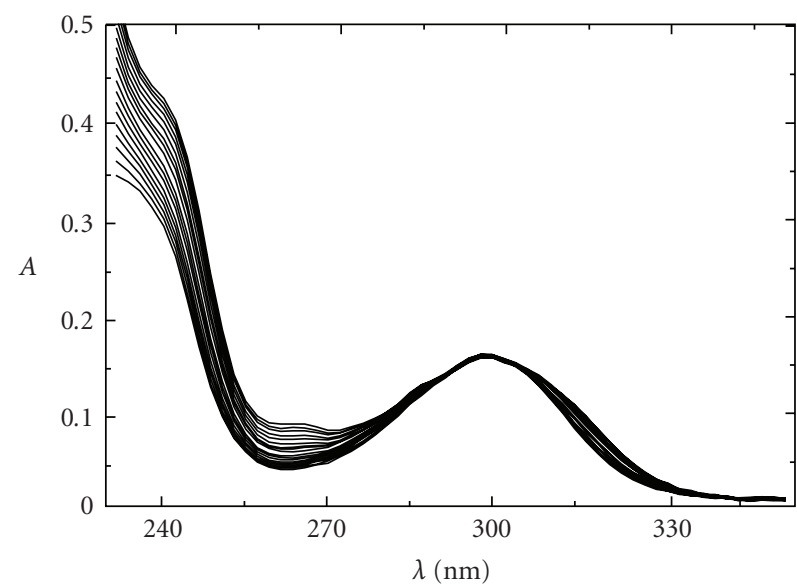

(a)

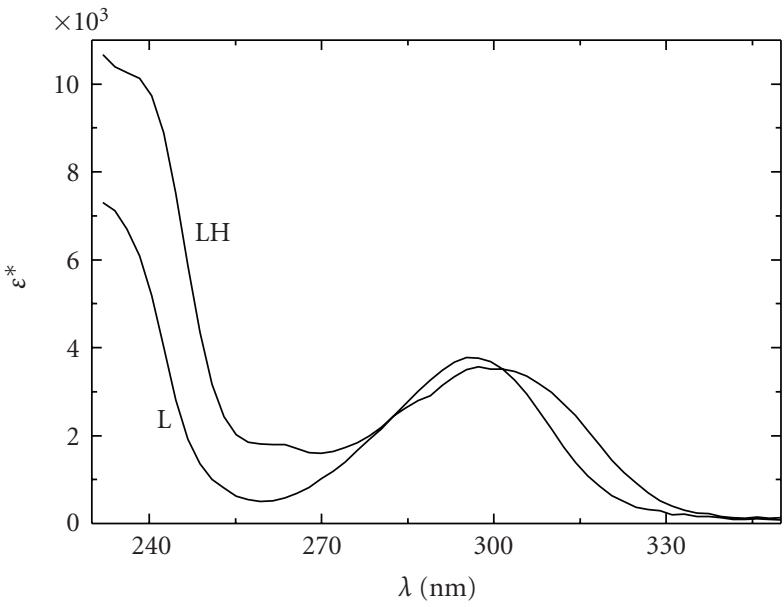

(c)

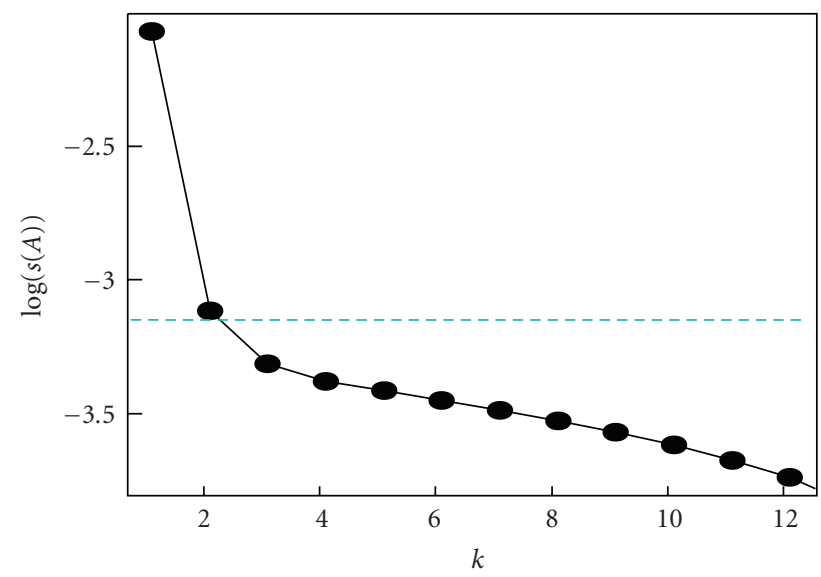

(b)

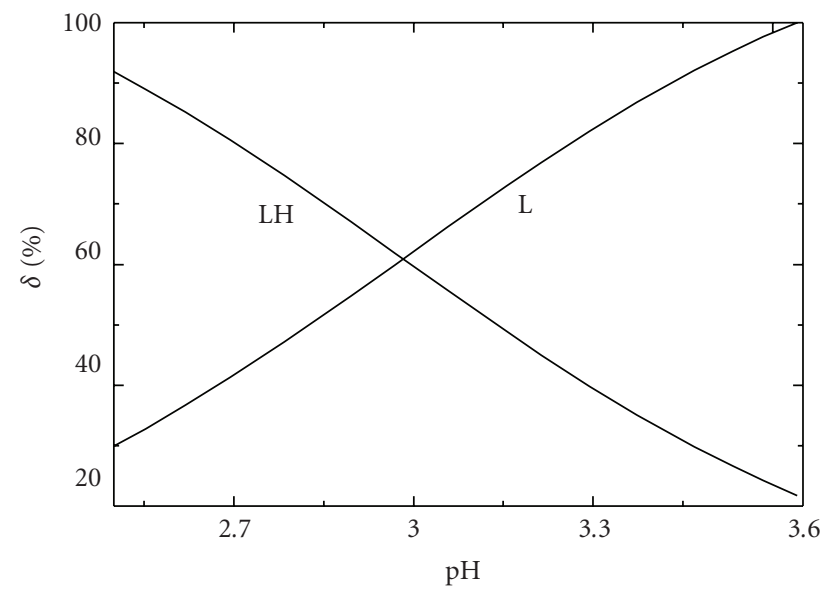

(d)

FIGURE 4: The nonlinear regression analysis of the protonation equilibria model and factor analysis of salicylic acid: (a) Absorption spectra in dependence on $\mathrm{pH}$ at $25^{\circ} \mathrm{C}$, (b) Cattel's scree plot of the Wernimont-Kankare procedure for determination of the number of light-absorbing species in the mixture $k^{*}=2$ leads to the actual instrumental error of the spectrophotometer used $s_{\text {inst }}(A)=0.71 \mathrm{mAU}$ (INDICES in S-Plus), (c) Pure spectra profiles of molar absorptivities versus wavelengths for species L and LH, (d) Distribution diagram of the relative concentrations of species $\mathrm{L}$ and $\mathrm{LH}$ of salicylic acid in dependence on $\mathrm{pH}$ at $25^{\circ} \mathrm{C}$. The charges of species are omitted for the sake of simplicity. (SPECFIT, ORIGIN).

TABLE 6: Dependence of the mixed dissociation constants $\mathrm{p} K_{\mathrm{a}}$ of galanthamine on ionic strength using regression analysis of $\mathrm{pH}$ spectrophotometric data with SPECFIT at $25^{\circ} \mathrm{C}$ and $37^{\circ} \mathrm{C}$. The standard deviations of the parameter p $K_{\mathrm{a}}$ in the last valid digits are in brackets.

\begin{tabular}{|c|c|c|c|c|c|c|c|c|c|c|c|}
\hline & \multicolumn{11}{|c|}{ Estimated $\mathrm{p} K_{\mathrm{a}}$ at $25^{\circ} \mathrm{C}$} \\
\hline \multirow{4}{*}{ SPECFIT } & Ionic strength & 0.070 & 0.096 & 0.136 & 0.136 & 0.163 & 0.255 & 0.322 & 0.348 & 0.415 & 0.507 \\
\hline & $\mathrm{p} K_{\mathrm{a}}$ & $8.224(5)$ & $8.241(6)$ & $8.263(6)$ & $8.291(4)$ & $8.281(9)$ & $8.309(4)$ & $8.357(4)$ & $8.330(6)$ & $8.391(8)$ & $8.409(4)$ \\
\hline & $s(\mathrm{~A})[\mathrm{mAU}]$ & 0.90 & 1.07 & 1.12 & 0.87 & 1.74 & 0.93 & 0.84 & 1.03 & 1.43 & 0.83 \\
\hline & \multicolumn{11}{|c|}{ Estimated $\mathrm{p} K_{\mathrm{a}}$ at $37^{\circ} \mathrm{C}$} \\
\hline \multirow{3}{*}{ SPECFIT } & Ionic strength & 0.017 & 0.030 & 0.083 & \multicolumn{2}{|c|}{0.110} & 0.176 & 0.229 & \multicolumn{2}{|c|}{0.269} & 0.362 \\
\hline & $\mathrm{p} K_{\mathrm{a}}$ & $7.989(11)$ & $8.027(6)$ & $8.049(5)$ & \multicolumn{2}{|c|}{$8.015(11)$} & $8.109(7)$ & $8.091(5)$ & \multicolumn{2}{|c|}{$8.147(5)$} & $8.183(6)$ \\
\hline & $s(\mathrm{~A})[\mathrm{mAU}]$ & 2.39 & 1.38 & 1.00 & \multicolumn{2}{|c|}{1.39} & 1.63 & 1.15 & \multicolumn{2}{|c|}{0.98} & 1.16 \\
\hline
\end{tabular}

allows absorbance-response data (Figure 3(a)) to be acquired for analysis by nonlinear regression, and the reliability of parameter estimates $\left(\mathrm{p} K_{\mathrm{s}}^{\prime}\right.$ and $\varepsilon_{\mathrm{s}}^{\prime}$ ) can be assessed on the basis of the goodness-of-fit test of residuals. The best region of the spectrum seems to be $220-350 \mathrm{~nm}$ and $\mathrm{p} K_{\mathrm{a}}=3.49(25)$.
Most of the selected methods of factor analysis by the INDICES algorithm lead to two light-absorbing components in the equilibrium mixture (Figure $3(\mathrm{~b})$ ). The position of the break point on the $s_{k}(A)=f(k)$ curve in the factor analysis scree plot is calculated and gives $k^{*}=2$ with 


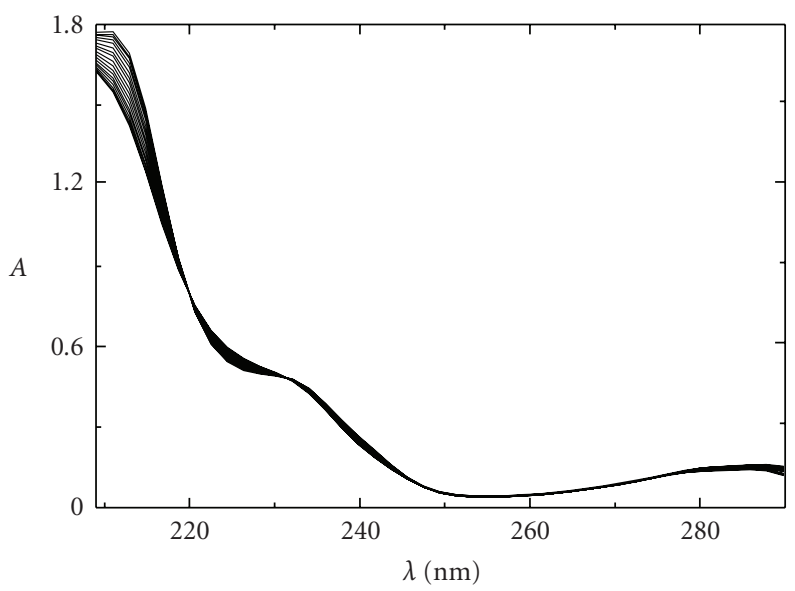

(a)

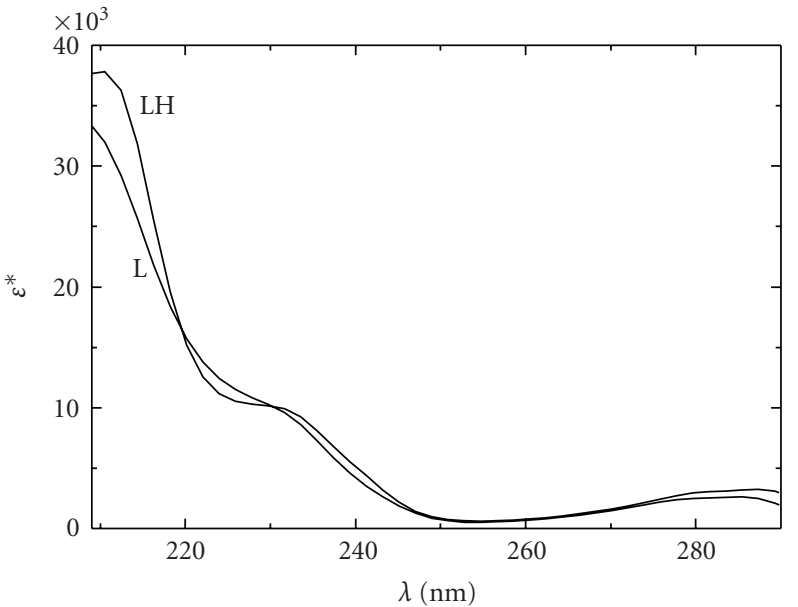

(c)

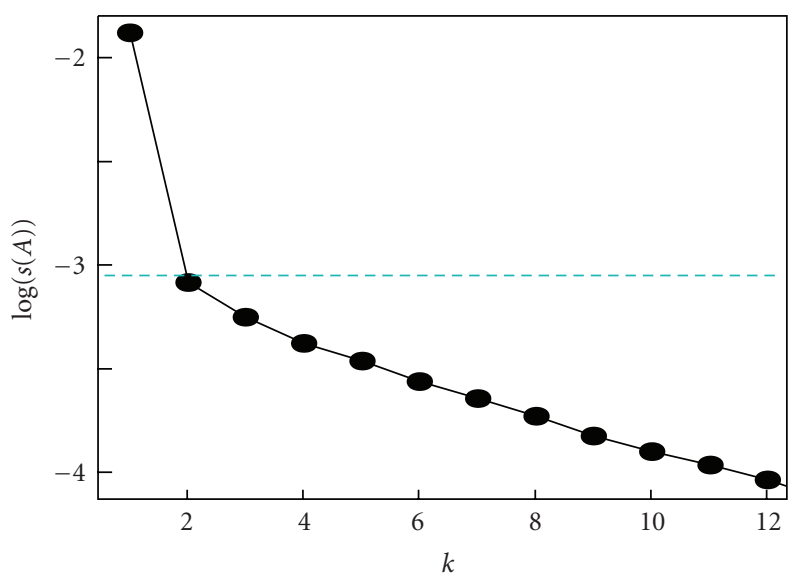

(b)

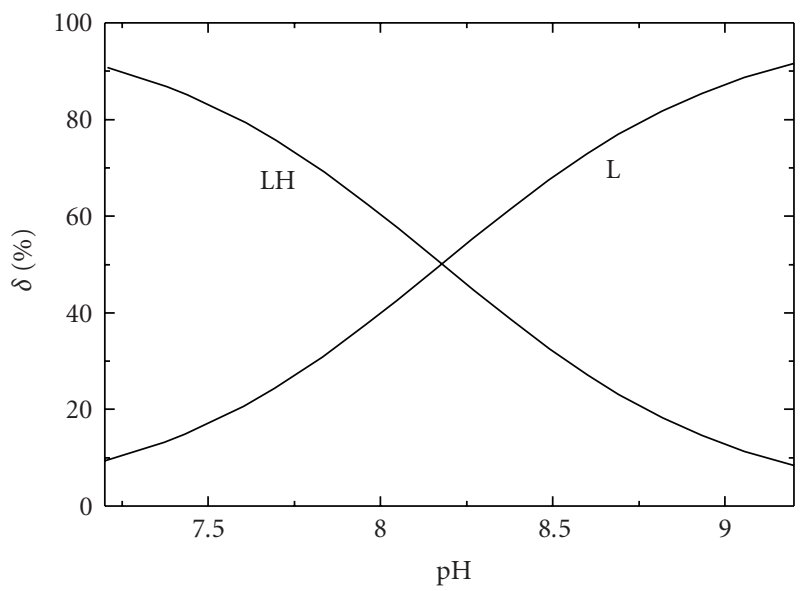

(d)

FIGURE 5: The nonlinear regression analysis of the protonation equilibria model and factor analysis of galanthamine: (a) Absorption spectra in dependence on $\mathrm{pH}$ at $25^{\circ} \mathrm{C}$, (b) Cattel's scree plot of the Wernimont-Kankare procedure for determination of the number of lightabsorbing species in the mixture $k^{*}=2$ leads to the actual instrumental error of the spectrophotometer used $s_{\text {inst }}(A)=1.00 \mathrm{mAU}(\mathrm{INDICES}$ in S-Plus), (c) Pure spectra profiles of molar absorptivities versus wavelengths for species L and LH, (d) Distribution diagram of the relative concentrations of species $\mathrm{L}$ and $\mathrm{LH}$ of salicylic acid in dependence on $\mathrm{pH}$ at $25^{\circ} \mathrm{C}$. The charges of species are omitted for the sake of simplicity. (SPECFIT, ORIGIN).

TABle 7: Thermodynamic dissociation constants $\mathrm{p} K_{a}^{T}$ for clotrimazole, terbinafine $\mathrm{HCl}$, acetylsalicylic acid, salicylic acid and galanthamine at two temperatures $25^{\circ} \mathrm{C}$ and $37^{\circ} \mathrm{C}$. The standard deviations in the last valid digits are in brackets.

\begin{tabular}{lccc}
\hline & $\mathrm{p} K_{\mathrm{a}}^{\mathrm{T}}$ at $25^{\circ} \mathrm{C}$ & $\mathrm{p} K_{\mathrm{a}}^{\mathrm{T}}$ at $37^{\circ} \mathrm{C}$ & $\mathrm{p} K_{\mathrm{a}}^{\mathrm{T}}($ Pharma $)$ \\
\hline Clotrimazole & $4.38(1)$ & $4.16(3)$ & $7.50 \pm 0.50$ \\
Terbinafine HCl & $4.19(3)$ & $4.12(5)$ & $7.00 \pm 0.50$ \\
Acetylsalicylic Acid & $3.49(25)$ & $3.41(15)$ & $3.50 \pm 0.50$ \\
Salicylic Acid & $3.01(1)$ & $3.00(1)$ & $3.00 \pm 0.50$ \\
Galanthamine & $8.21(1)$ & $7.99(2)$ & $8.60 \pm 0.50$ \\
\hline
\end{tabular}

the corresponding coordinate $\log \left(s_{k}^{*}(A)\right)=-3.10$ which gives the value $s_{k}^{*}(A)=0.79 \mathrm{mAU}$. The goodness-of-fit establishes sufficiently reliable estimate of the dissociation constant and molar absorption coefficient. Figure 3(c) shows curves of molar absorption coefficients of $\mathrm{L}^{-}$and $\mathrm{LH}$ species in dependence on wavelengths and Figure 3(d) shows the distribution diagram of $\mathrm{L}^{-}$and $\mathrm{LH}$ species in dependence on $\mathrm{pH}$. The repeatability of the estimated dissociation constant $\mathrm{p} K_{\mathrm{a}}$ and its mean value at two temperatures $25^{\circ} \mathrm{C}$ and $37^{\circ} \mathrm{C}$ at one ionic strength $I=0.001$ is in Table 3 .

3.1.4. Salicylic Acid. The experimental spectra are acquired for the titration of an alkaline $4.18 \times 10^{-5} \mathrm{M}$ salicylic acid solution by a standard solution of $1 \mathrm{M} \mathrm{HCl}\left(\right.$ or $\mathrm{HClO}_{4}$ ) to adjust $\mathrm{pH}$ value. $\mathrm{pH}$ spectrophotometric titration allows absorbance-response data (Figure 4(a)) to be acquired for analysis by nonlinear regression, and the reliability of parameter estimates $\left(\mathrm{p} K_{\mathrm{s}}^{\prime}\right.$ and $\varepsilon_{\mathrm{s}}^{\prime}$ ) can be assessed on the basis of the goodness-of-fit test of residuals. As the changes in spectra are quite small within deprotonation, however, both of the variously protonated species $\mathrm{L}^{-}$and LH exhibit 


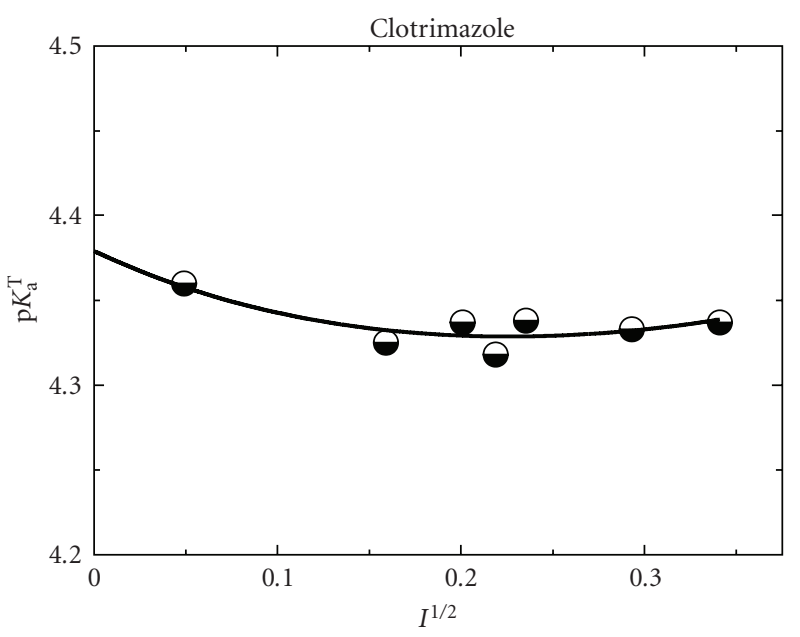

(a)

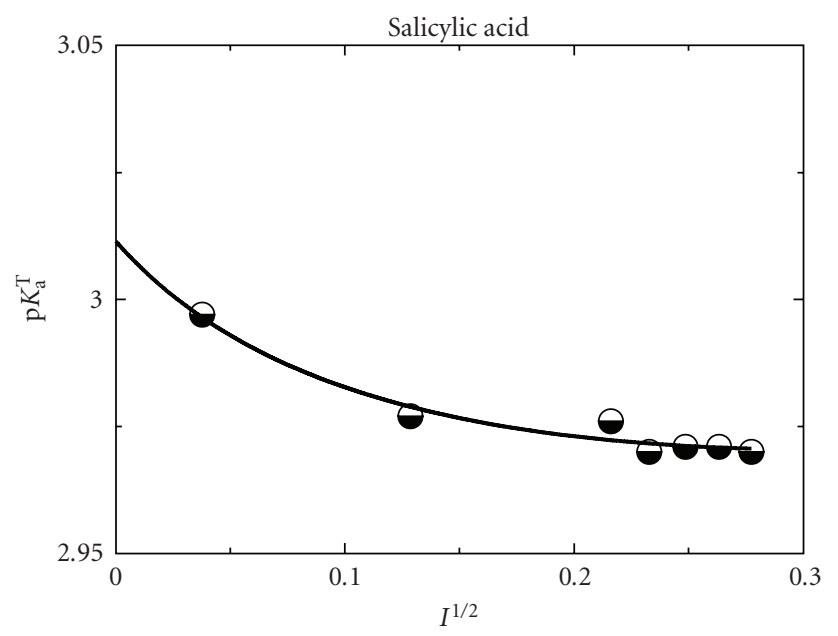

(c)

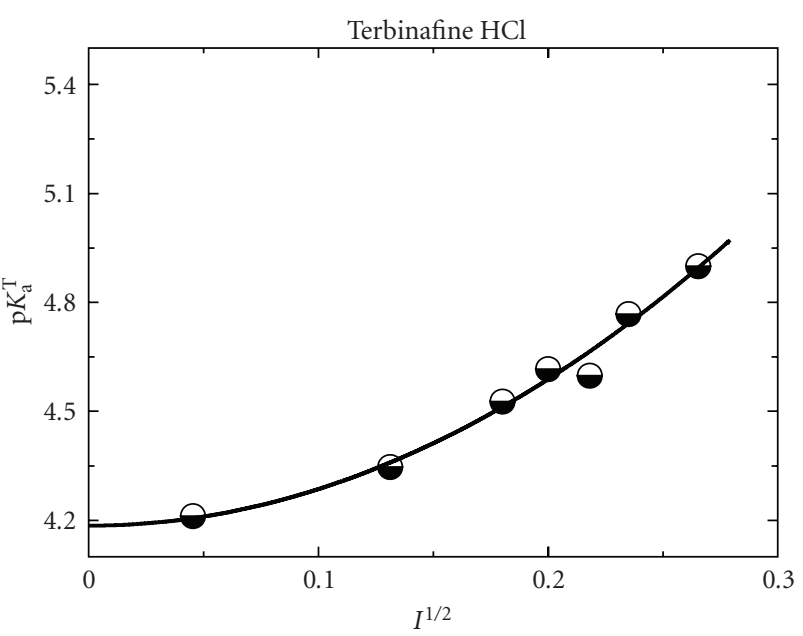

(b)

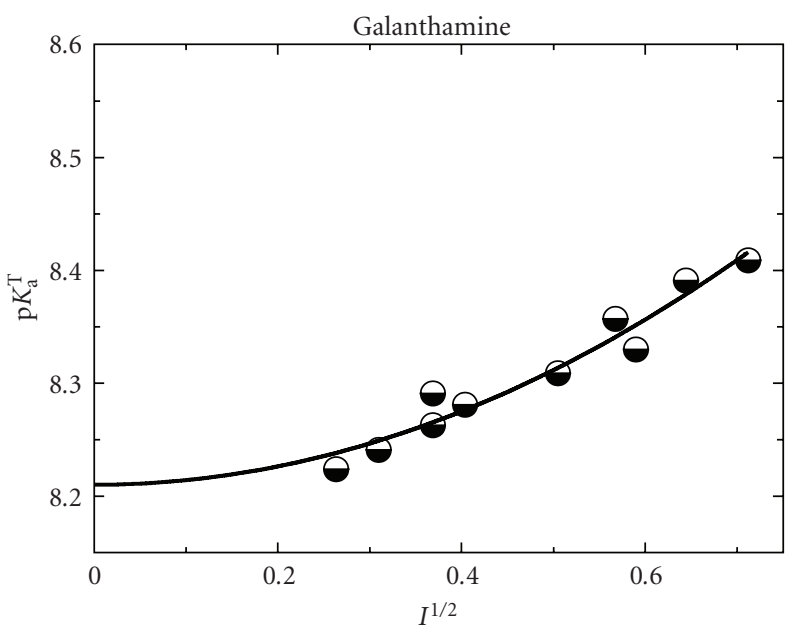

(d)

FIGURE 6: Dependence of the mixed dissociation constant $\mathrm{p} K_{a}$ of clotrimazole, terbinafine $\mathrm{HCl}$, salicylic acid and galanthamine on the square root of the ionic strength, leading to the thermodynamic dissociation constant $\mathrm{p} K_{\mathrm{a}}^{\mathrm{T}}$ at $25^{\circ} \mathrm{C}$, (ADSTAT, ORIGIN).

nearly similar absorption bands. In cases of small changes in spectra, a precise measurement of absorbance is necessary for a reliable detection of the deprotonation equilibrium studied. The best region of the spectrum seems to be 230 $350 \mathrm{~nm}$ and $\mathrm{p} K_{\mathrm{a}}=3.01(s=0.01)$. Most of the selected methods of factor analysis by the INDICES algorithm lead to two light-absorbing components in the equilibrium mixture (Figure $4(\mathrm{~b})$ ). The position of the break point on the $s_{k}(A)=$ $f(k)$ curve in the factor analysis scree plot is calculated and gives $k^{*}=2$ with the corresponding coordinate log $\left(s_{k}^{*}(A)\right)=-3.15$ which gives the value $s_{k}^{*}(A)=0.71 \mathrm{mAU}$ and which may also be taken here as the actual instrumental error $s_{\text {inst }}(A)$ of the spectrophotometer used. The goodnessof-fit establishes sufficiently reliable estimate of the dissociation constant and molar absorption coefficient. Figure 4(c) shows curves of molar absorption coefficients of $\mathrm{L}^{-}$and LH species in dependence on wavelengths and Figure 4(d) shows the distribution diagram of $\mathrm{L}^{-}$and $\mathrm{LH}$ species on $\mathrm{pH}$. The estimated dissociation constant $\mathrm{p} K_{\mathrm{a}}$ at two temperatures $25^{\circ} \mathrm{C}$ and $37^{\circ} \mathrm{C}$ on an ionic strength $I$ is in Table 4 and
Figure 6. The repeatability of the estimated dissociation constant $\mathrm{p} K_{\mathrm{a}}$ and its mean value at the temperature $25^{\circ} \mathrm{C}$ at one ionic strength $I=0.001$ are in Table 5 .

3.1.5. Galanthamine. The experimental spectra are acquired for the titration of an acid $4.71 \times 10^{-5} \mathrm{M}$ galanthamine solution by a standard solution of $1 \mathrm{M} \mathrm{NaOH}$ to adjust $\mathrm{pH}$ value. $\mathrm{pH}$ spectrophotometric titration allows absorbanceresponse data (Figure 5(a)) to be acquired for analysis by nonlinear regression, and the reliability of parameter estimates $\left(\mathrm{p} K_{\mathrm{s}}^{\prime}\right.$ and $\varepsilon_{\mathrm{s}}^{\prime}$ ) can be assessed on the basis of the goodness-of-fit test of residuals. As the changes in spectra are quite small within deprotonation, however, both of the variously protonated species $\mathrm{L}^{-}$and $\mathrm{LH}$ exhibit nearly similar absorption bands. The best region of the spectrum seems to be $209-290 \mathrm{~nm}$ and $\mathrm{p} K_{\mathrm{a}}=8.21(s=0.01)$. Most of the selected methods of factor analysis by the INDICES algorithm lead to two light-absorbing components in the equilibrium mixture (Figure 5(b)). The position of the break point on the $s_{k}(A)=f(k)$ curve in the factor 
analysis scree plot is calculated and gives $k^{*}=2$ with the corresponding coordinate $\log \left(s_{k}^{*}(A)\right)=-3.00$ which gives the value $s_{k}^{*}(A)=1.00 \mathrm{mAU}$. The goodness-of-fit establishes sufficiently reliable estimate of the dissociation constant and molar absorption coefficient. Figure 5(c) shows curves of molar absorption coefficients of $\mathrm{L}^{-}$and $\mathrm{LH}$ species in dependence on wavelengths and Figure 5(d) shows the distribution diagram of $\mathrm{L}^{-}$and $\mathrm{LH}$ species in dependence on $\mathrm{pH}$. The estimated dissociation constant $\mathrm{p} K_{\mathrm{a}}$ at two temperatures $25^{\circ} \mathrm{C}$ and $37^{\circ} \mathrm{C}$ in dependence on an ionic strength $I$ is in Table 6 and Figure 6 .

3.2. Thermodynamic Dissociation Constants. The thermodynamic dissociation constants as the unknown parameter $\mathrm{p} K_{\mathrm{a}}^{\mathrm{T}}$ were estimated by applying a Debye-Hückel equation to the data in Tables 1, 2, 4, 6, and Figure 6 according to the regression criterion; Table 7 shows point estimates of the thermodynamic dissociation constants of the five drugs (clotrimazole, terbinafine $\mathrm{HCl}$, acetylsalicylic acid, salicylic acid, and galanthamine) at two temperatures. Because of the narrow range of ionic strengths the ion-size parameter and the salting-out coefficient $C$ could not be estimated.

\section{Conclusions}

When drugs are very poorly soluble, $\mathrm{pH}$-spectrophotometric titration may be used with non-linear regression of the absorbance-response-surface data instead of performing a potentiometric determination of the dissociation constants. The reliability of the dissociation constants of the five drugs (clotrimazole, terbinafine $\mathrm{HCl}$, acetylsalicylic acid, salicylic acid, and galanthamine) may be proven with goodness-offit tests of the absorption spectra measured at various $\mathrm{pH}$. The dissociation constant $\mathrm{p} K_{\mathrm{a}}$ was estimated by non-linear regression of $\left\{\mathrm{p} K_{\mathrm{a}}, I\right\}$ data at $25^{\circ} \mathrm{C}$ : for clotrimazole $\mathrm{p} K_{\mathrm{a}, 1}^{\mathrm{T}}=$ 4.38(1), for terbinafine $\mathrm{HCl} K_{\mathrm{a}, 1}^{\mathrm{T}}=4.19(3)$, for acetylsalicylic acid $\mathrm{p} K_{\mathrm{a}, 1}^{\mathrm{T}}=3.49(25)$, for salicylic acid $\mathrm{p} K_{\mathrm{a}, 1}^{\mathrm{T}}=3.01(1)$, and for galanthamine $\mathrm{p} K_{\mathrm{a}, 1}^{\mathrm{T}}=8.21(1)$, where in brackets is the standard deviation in last significant digits. Goodnessof-fit tests for various regression diagnostics enable the reliability of the parameter estimates to be determined.

\section{Acknowledgment}

The financial support of the Grant Agency IGA MZ ČR (Grants nos. NR-9055-4/2006 and NS9831-4/2008) and of the Czech Ministry of Education (Grant no. MSM0021627502) is gratefully acknowledged.

\section{References}

[1] M. Meloun, J. Havel, and E. Högfeldt, Computation of Solution Equilibria, Ellis Horwood, Chichester, UK, 1988.

[2] M. Meloun and J. Havel, Computation of Slution Equilibria, 1. Spectrophotometry, Folia Facultatis Scientarum Naturalium Universitatis Prkkynianae Brunensis (Chemia), XXV, Jan Evangelista Purkyně University, Brno, Czech Republic, 1984.

[3] M. Meloun and J. Havel, Computation of solution equilibria, 2. Potentiometry, Folia Facultatis Scientarum Naturalium
Universitatis Prkkynianae Brunensis (Chemia), XXVI, Jan Evangelista Purkyně University, Brno, Czech Republic, 1985.

[4] L. Zékány and I. Nagypál, in Computational Methods for the Determination of Formation Constants, D. J. Leggett, Ed., pp. 99-157, Plenum Press, New York, NY, USA, 1985.

[5] L. Zékány and I. Nagypál, "PSEQUAD: a comprehensive program for the evaluation of potentiometric and/or spectrophotometric equilibrium data using analytical derivatives," in Computational Methods for the Determination of Formation Constants, D. J. Leggett, Ed., pp. 291-353, Plenum Press, New York, NY, USA, 1985.

[6] J. Havel and M. Meloun, in Computational Methods for the Determination of Formation Constants, D. J. Leggett, Ed., p. 19, Plenum Press, New York, NY, USA, 1985.

[7] J. Havel and M. Meloun, in Computational Methods for the Determination of Formation Constants, D. J. Leggett, Ed., p. 221, Plenum Press, New York, NY, USA, 1985.

[8] M. Meloun, M. Javůrek, and J. Havel, "Multiparametric curve fitting-X. A structural classification of programs for analysing multicomponent spectra and their use in equilibrium-model determination," Talanta, vol. 33, no. 6, pp. 513-524, 1986.

[9] D. J. Leggett and W. A. E. McBryde, "General computer program for the computation of stability constants from absorbance data," Analytical Chemistry, vol. 47, no. 7, pp. 1065-1070, 1975.

[10] D. J. Leggett, "Numerical analysis of multicomponent spectra," Analytical Chemistry, vol. 49, no. 2, pp. 276-281, 1977.

[11] D. J. Leggett, S. L. Kelly, L. R. Shiue, Y. T. Wu, D. Chang, and K. M. Kadish, "A computational approach to the spectrophotometric determination of stability constants-II. Application to metalloporphyrin-axial ligand interactions in non-aqueous solvents," Talanta, vol. 30, no. 8, pp. 579-586, 1983.

[12] H. Gampp, M. Maeder, C. J. Meyer, and A. D. Zuberbühler, "Calculation of equilibrium constants from multiwavelength spectroscopic data-I. Mathematical considerations," Talanta, vol. 32, no. 2, pp. 95-101, 1985.

[13] H. Gampp, M. Maeder, C. J. Meyer, and A. D. Zuberbühler, "Calculation of equilibrium constants from multiwavelength spectroscopic data-II: specfit: two user-friendly programs in basic and standard fortran 77," Talanta, vol. 32, no. 4, pp. 251264, 1985.

[14] H. Gampp, M. Maeder, C. J. Meyer, and A. D. Zuberbühler, "Calculation of equilibrium constants from multiwavelength spectroscopic data-III: model-free analysis of spectrophotometric and ESR titrations," Talanta, vol. 32, no. 12, pp. 11331139, 1985.

[15] H. Gampp, M. Maeder, C. J. Meyer, and A. D. Zuberbühler, "Calculation of equilibrium constants from multiwavelength spectroscopic data-IV: model-free least-squares refinement by use of evolving factor analysis," Talanta, vol. 33, no. 12, pp. 943-951, 1986.

[16] "SPECFIT/32: Spectrum Software Associates," 197M Boston Post Road West, Marlborough, Mass, USA, 2004, http:// www.bio-logic.info/rapid-kinetics/support.htmll.

[17] Pharma Algorithms, http://pharma-algorithms.com/index .html.

[18] R. Hájková, H. Sklenářová, L. Matysová, P. Švecová, and P. Solich, "Development and validation of HPLC method for determination of clotrimazole and its two degradation products in spray formulation," Talanta, vol. 73, no. 3, pp. 483-489, 2007.

[19] O. H. Abdelmageed and P. Y. Khashaba, "Spectrophotometric determination of clotrimazole in bulk drug and dosage forms," Talanta, vol. 40, no. 8, pp. 1289-1294, 1993. 
[20] M.-Y. Ning, Y.-Z. Guo, H.-Z. Pan, H.-M. Yu, and Z.-W. $\mathrm{Gu}$, "Preparation and evaluation of proliposomes containing clotrimazole," Chemical and Pharmaceutical Bulletin, vol. 53, no. 6, pp. 620-624, 2005.

[21] P. Mikuš, I. Valášková, and E. Havránek, "Determination of terbinafine in pharmaceuticals and dialyzates by capillary electrophoresis," Talanta, vol. 65, no. 4, pp. 1031-1037, 2005.

[22] L. Matysová, P. Solich, P. Marek, L. Havlíková, L. Nováková, and J. Sícha, "Separation and determination of terbinafine and its four impurities of similar structure using simple RP-HPLC method," Talanta, vol. 68, no. 3, pp. 713-720, 2006.

[23] Y. S. El-Saharty, N. Y. Hassan, and F. H. Metwally, "Simultaneous determination of terbinafine HCL and triamcinolone acetonide by UV derivative spectrophotometry and spectrodensitometry," Journal of Pharmaceutical and Biomedical Analysis, vol. 28, no. 3-4, pp. 569-580, 2002.

[24] The Merck Index, An Encyclopedia of Chemicals, Drugs and Biologicals, Merck, Whitehouse Station, NJ, USA, 12th edition, 1996.

[25] J. R. Vane and R. M. Botting, Eds., Aspirin and Other Salicylates, Chapman \& Hall, London, UK, 1992.

[26] E. H. Awtry and J. Loscalzo, "Aspirin," Circulation, vol. 101, no. 10, pp. 1206-1218, 2000.

[27] D. Lacey, X. K. Hu, A. V. Loboda, N. J. Mosey, and R. H. Lipson, "Aspirin revealed: a cationization strategy for detecting acetylsalicylic acid by MALDI mass spectrometry," International Journal of Mass Spectrometry, vol. 261, no. 2-3, pp. 192-198, 2007.

[28] R. S. Sandler, M. L. S. Halabi, and J. A. Baron, "Daily aspirin may reduce the risk of colorectal adenoma in people with a history of colorectal cancer," Cancer Treatment Reviews, vol. 29, no. 4, pp. 329-335, 2003.

[29] T. Phillips and C. Leeuwenburgh, "Lifelong aspirin supplementation as a means to extending life span," Rejuvenation Research, vol. 7, no. 4, pp. 243-251, 2004.

[30] A. Ruiz-Medina, M. L. Fernández de Córdova, P. OrtegaBarrales, and A. Molina Díaz, "Flow-through UV spectrophotometric sensor for determination of (acetyl)salicylic acid in pharmaceutical preparations," International Journal of Pharmaceutics, vol. 216, no. 1-2, pp. 95-104, 2001.

[31] H. Ch. Loh, M. Ahmad, and M. N. Taib, "A novel salicylic acid optical fibre probe fabrication," Sensors and Actuators B, vol. 107, no. 1, pp. 59-63, 2005.

[32] L. J. Scott and K. L. Goa, "Galantamine: a review of its use in Alzheimer's disease," Drugs, vol. 60, no. 5, pp. 1095-1122, 2000.

[33] G. Krejčová and L. Ševelová, "Současné poznatky o galantaminu, reverzibilním inhibitoru acetylcholinesterázy," Vojenské Zdravotnické Listy, vol. 72, no. 2, pp. 37-44, 2003.

[34] C. Bartolucci, E. Perola, Ch. Pilger, G. Fels, and D. Lamba, "Three-dimensional structure of a complex of galanthamine (Nivalin ${ }^{\circledR}$ ) with acetylcholinesterase from Torpedo californica: implications for the design of new anti-Alzheimer drugs," Proteins: Structure, Function and Genetics, vol. 42, no. 2, pp. 182-191, 2001.

[35] J. Maláková, M. Nobilis, Z. Svoboda, et al., "Highperformance liquid chromatographic method with UV photodiode-array, fluorescence and mass spectrometric detection for simultaneous determination of galantamine and its phase I metabolites in biological samples," Journal of Chromatography B, vol. 853, no. 1-2, pp. 265-274, 2007.

[36] L. Marco and M. do Carmo Carreiras, "Galanthamine, a natural product for the treatment of Alzheimer's disease,"
Recent Patents on CNS Drug Discovery, vol. 1, no. 1, pp. 105111, 2006.

[37] M. Meloun, S. Bordovská, T. Syrový, and A. Vrána, “Tutorial on a chemical model building by least-squares nonlinear regression of multiwavelength spectrophotometric $\mathrm{pH}$ titration data," Analytica Chimica Acta, vol. 580, no. 1, pp. 107-121, 2006.

[38] M. Meloun, S. Bordovská, and A. Vrána, "The thermodynamic dissociation constants of the anticancer drugs camptothecine, 7-ethyl-10-hydroxycamptothecine, 10-hydroxycamptothecine and 7-ethylcamptothecine by the least-squares nonlinear regression of multiwavelength spectrophotometric $\mathrm{pH}$ titration data," Analytica Chimica Acta, vol. 584, no. 2, pp. 419-432, 2007.

[39] M. Meloun, T. Syrový, S. Bordovská, and A. Vrána, "Reliability and uncertainty in the estimation of $\mathrm{pK}$ a by least squares nonlinear regression analysis of multiwavelength spectrophotometric $\mathrm{pH}$ titration data," Analytical and Bioanalytical Chemistry, vol. 387, no. 3, pp. 941-955, 2007.

[40] M. Meloun, S. Bordovská, and L. Galla, "The thermodynamic dissociation constants of four non-steroidal antiinflammatory drugs by the least-squares nonlinear regression of multiwavelength spectrophotometric pH-titration data," Journal of Pharmaceutical and Biomedical Analysis, vol. 45, no. 4, pp. 552-564, 2007.

[41] M. Meloun, J. Militký, and M. Forina, Chemometrics for Analytical Chemistry, Vol. 1. PC-Aided Statistical Data Analysis, Ellis Horwood, Chichester, UK, 1992.

[42] M. Meloun, J. Militký, and M. Forina, Chemometrics for Analytical Chemistry, Vol. 2. PC-Aided Regression and Related Methods, Ellis Horwood, Chichester, UK, 1994.

[43] M. Meloun, V. Ríha, and J. Žáček, "Stavebnicová pistová mikrobyreta pro dávkovaní agresivních roztoků," Chemické Listy, vol. 82, pp. 765-767, 1988.

[44] M. Meloun, S. Bordovská, and T. Syrový, "A novel computational strategy for the $\mathrm{pKa}$ estimation of drugs by nonlinear regression of multiwavelength spectrophotometric $\mathrm{pH}$ titration data exhibiting small spectral changes," Journal of Physical Organic Chemistry, vol. 20, no. 9, pp. 690-701, 2007.

[45] M. Meloun, S. Bordovská, and L. Galla, "The thermodynamic dissociation constants of four non-steroidal antiinflammatory drugs by the least-squares nonlinear regression of multiwavelength spectrophotometric pH-titration data," Journal of Pharmaceutical and Biomedical Analysis, vol. 45, no. 4, pp. 552-564, 2007.

[46] M. Meloun and S. Bordovská, "Benchmarking and validating algorithms that estimate $\mathrm{pK}$ a values of drugs based on their molecular structures," Analytical and Bioanalytical Chemistry, vol. 389, no. 4, pp. 1267-1281, 2007.

[47] M. Meloun, S. Bordovská, and A. Vrána, "The thermodynamic dissociation constants of the anticancer drugs camptothecine, 7-ethyl-10-hydroxycamptothecine, 10-hydroxycamptothecine and 7-ethylcamptothecine by the least-squares nonlinear regression of multiwavelength spectrophotometric $\mathrm{pH}$ titration data," Analytica Chimica Acta, vol. 584, no. 2, pp. 419-432, 2007.

[48] M. Meloun, T. Syrový, S. Bordovská, and A. Vrána, "Reliability and uncertainty in the estimation of $\mathrm{pK}$ a by least squares nonlinear regression analysis of multiwavelength spectrophotometric $\mathrm{pH}$ titration data," Analytical and Bioanalytical Chemistry, vol. 387, no. 3, pp. 941-955, 2007.

[49] ORIGIN: OriginLab Corporation, One Roundhouse Plaza, Northampton, Mass, USA. 
[50] S-PLUS: http://www.insightful.com/products/splus.

[51] ADSTAT: ADSTAT 1.25, 2.0, 3.0 (Windows 95), TriloByte Statistical Software Ltd., Pardubice, Czech Republic.

[52] M. Meloun, T. Syrový, and A. Vrána, "Determination of the number of light-absorbing species in the protonation equilibra of selected drugs," Analytica Chimica Acta, vol. 489, no. 2, pp. 137-151, 2003. 